\title{
第28回日本老年医学会総会記録 一般演題 $(\mathrm{V})$
}

\section{7. 赤血球膜脂質成分に関する研究 (第 3 報)ビフィ ズス菌投与による赤血球膜リン脂質成分と赤血球浸透 圧脆弱性の変化 \\ 多摩成人病研究所 \\ 涉谷 正行, 牛尾 博昭, 牛尾 盛保 キリンビール麦酒科学研究所藤野 舜一}

目的：高齢者に便秘症例が多いことは周知のことで あり, 特に中枢麻痺を伴う寝たきり高齢者の便秘症は 避けがたい合併症の一つである。一方，寝たきり高齢 者の䔬便内細菌叢では成人に比してビフィズス菌の有 意な減少が認められている，上述のことを踏まえて， 高齢で寝たきりの便秘症例にビフィズス菌を投与し て, 排便状態と血浆脂質成分拈よび赤血球浸透圧脆弱 性ならびに赤血球膜リン脂質成分を観察した。

方法：脳血管障害揖よび脳血管障害後遺症で漫たき りの 10 例 (男 3 例，女 7 例) 平均 $82.0 \pm 9.7$ 歳に粉末 1 グラム中にビフィズス菌42億含有 (ビ菌)を 2 週間 ( 1 回/ 1 日)経口投与して投与前と後の臨床検査成績を比 較した。また，便秘症例と非便秘例の臨床検查成績に ついても合わせて検討した。な抢，赤血球浸透圧脆弱 性試験（動的赤血球膜物性検査）はコイルプラネット 法（CPC）を用い，赤血球膜リン脂質構成成分はヤト ロスキャン法（TLC-FID）を用いて分画した，

結果：(1)便秘症例は非便秘例に比して CPC 法によ る赤血球浸透圧脆弱性に招いて水やイオンの透過性に 障害を有する赤血球が増加していた。 (2)便秘症例と非 便秘例の血奨脂質成分に有意差はみられなかった。(3) ビ菌投与後, 赤血球膜の水やイオンの透過性に改善が みられた. (4)ビ菌投与後, 赤血球膜リン脂質構成成分 のホスファチジルイノシトール(PI), ホスファチジル セリン (PS) 分画に有意の増加とスフィンゴミェリン （SM）分画の減少傾向がみられた。 (5)ビ菌投与後, 䔬 便内のビ菌数に有意の増加を認めた。 (6)排便状態につ いては対象者が瀉下薬常用者であったためビ菌による 排便効果を正確に把籍し觉なかった。以上のことから ビフィズス菌は寝たきり高齢便秘症例の赤血球膜にみ られる水やイオンの透過障害に改善を促すことが示唆 され，その要因として膜リン脂質の PI, PS および SM の変化が考学られた。
性について一

東京医大老年科

近食 櫻, 勝沼 英宇, 今村 敏治

目的：老年に伴い動脈硬化を base にする虚血性病 変は流動する赤血球量と赤血球が運搬する酸素量の不 足, すなわち赤血球変形能の低下によると考只られて いる. 一方赤血球膜脂質にも変動を生じており, 正常 者及び幼若赤血球に対し高コレステロール血症及び老 化赤血球では赤血球膜遊離コレステロールは著明に増 加するが，膜リン脂質は減少，特に膜リン脂質中の多 価不飽和脂肪酸が減少すると報告がなされている。膜 変形能は in vitroでは Nucleopore filtration 法によ り検討がなされているが, 今回我々は家鬼の脾臓を使 用し, in vivo で上記赤血球の膜変形能を証明し壳たの で報告する。

方法：(1)体重2.5 3.0kg の白色雄性家鬼を使用し, $\mathrm{N}$ 群, $\mathrm{C}$ 群, $\mathrm{T}$ 群の 3 群に分けて飼育した(飼料は $1 \%$ コレステロール含有食を使用, 飼育期間は 20 週). $\mathrm{N}$ 群 は正常食飼育群, C 群は $1 \%$ コレステロール食飼育群, $\mathrm{T}$ 群は $1 \%$ ユレステロール食及び pentoxifilline 注射 ( $10 \mathrm{mg} / \mathrm{kg})$ で飼育した.

(2), (1)の家鬼とは別の体重2.5 3.0kg の白色雄性家 鬼の脾動脈並びに静脈にカニュレーションを行ない, 生理食塩水により脾臟内血液を洗浄する。その後(1)の 群より採血した血液をもって灌流を行なった。脾静脈 より流出する血液を採取し, それぞれの赤血球数, 脂 肪酸量, 脂肪酸組成割合を測定する。な和灌流前後の 血液塗抹標本並びに灌流脾の電顕像を観察した。

結果： 3 群の赤血球数減少率は $\mathrm{N}$ 群 $4.92 \pm 0.71 \%$, $\mathrm{C}$ 群 $16.10 \pm 5.88 \%$, T 群 $9.13 \pm 3.17 \%$ となり, 減少率 は $\mathrm{N}$ 群, $\mathrm{T}$ 群, $\mathrm{C}$ 群の順に大きい。 また 3 群の脂肪酸 量もこの順に大きい。一方 3 群の灌流前の不飽和脂肪 酸：飽和脂肪酸比は $\mathrm{N}$ 群, $\mathrm{T}$ 群, $\mathrm{C}$ 群の順に減少傾向 を示したが多価不飽和脂肪酸は $\mathrm{C}$ 群, $\mathrm{T}$ 群で等しい傾 向にあり, $\mathrm{N}$ 群では前 2 者に比べ大きい. 又前後で $\mathrm{N}$ 群, C 群共に多価不飽和脂肪酸が減少したが, $\mathrm{T}$ 群で は変動が認められなかった。

289. 老年者の鉄欠乏の検討，とくに瀉血後鉄欠乏に ついて

群馬大分院内科 田村 遵一, 新井 利政 
久保田一雄, 白倉 卓夫

目的：老化に伴って血中鉄レベルを示す血清鉄 $(\mathrm{SI})$ は漸減する一方，貯蔵鉄の指標としての血清フェリチ ン $(\mathrm{SFt})$ は増加することが知られている，今回，各種 多血症における䵘血による急性鉄欠乏発現時の鉄関連 パラメーターの諸変化を検討し，老年者鉄欠乏につき 考察を加光ることを目的とした。

対象と方法：対象は66歳より 75歳(平均年齢68.8歳) の男性で, ストレス多血症 1 例, 肺線維症に続発した 二次性多血症 4 例である. 瀉血は $12 \sim 15 \mathrm{~m} l / \mathrm{kg}$ の割合 で， 1 週間内に 3 回に分けて施行した. SI 及び総鉄結 合能 (TIBC) は Ferrochem 3050, SFtは SPACフェ フェリチンキットでそれぞれ測定した。

結果：瀉血後の SI の低下に伴って, TIBC は増加し たが，両者の関係をSI と TIBC の回帰直線から見る と, これら瀉血例では, 老年対象群 $(\mathrm{Y}=0.17 \mathrm{X}+275$, $\mathrm{n}=65, \mathrm{Y}: \mathrm{TIBC}, \mathrm{X}: \mathrm{SI})$ 加若年対象群 $(\mathrm{Y}=486-$ 0.47X, $\mathrm{n}=130$ )に接近する傾向で変化した。トランス フェリン飽和率 (Tf. Sat) も同様に老年者群 $(\mathrm{Y}=0.20$ $\mathrm{X}+10.6, \mathrm{Y}:$ Tf. Sat, $\mathrm{X}: \mathrm{SI})$ より若年者群 $(\mathrm{Y}=0.24$ $\mathrm{X}-1.6$ ）に偏る傾向を示した。 SFtは老年者群（Y= $0.49 \mathrm{X}+25.4, \mathrm{Y}: \mathrm{SFt}, \mathrm{X}: \mathrm{SI})$ より若年者群 $(\mathrm{Y}=0.08$ $\mathrm{X}+3.8$ ) に偏る傾向が見られたが, SFt 減少は SI 低下 程度に比して軽度であった。鉄治療によく反応した老 年者鉄欠乏性貧血例中には, SI の低下, TIBC の増加 が見られるものの $\mathrm{SFt}$ 值は $20 \mathrm{ng} / \mathrm{m} l$ 以上の正常下限 に留まる例があった。

結論：老年者に扮いては，急性鉄欠乏時に貯蔵鉄の 異常低下の先行がみられず，又慢性鉄欠乏性貧血時に 貯蔵鉄の枯渴が考光られなくても，血中鉄レベルが低 下している例がある。この点は，老年者の鉄欠乏診断 にさいして留意すべき点でもある。

290. 老年者赤血球増加症に関する研究（第 2 報）動 脈硬化症との関連について

都老人医療センター内科

村井 善郎, 平井真希子, 倉田 寛一

深山 牧子, 三輪 哲義, 森 真由美

名倉 博史

老年者男性で赤血球増加例中，脳血管障害を高率に 合併することは，しばしば経験するところである，今 回我々は赤血球増加症 (EC と略) の発現頻度々, 基礎 疾患について検討し，その病態に関し考察を加えた。

対象は昭和 50 年から約 9 年間に当院で死亡した男性
例で入院時血算が施行された例は，1,584例で，らち $\mathrm{Hb} 16.0 \mathrm{~g} / \mathrm{d} l$ 以上の $\mathrm{EC}$ は 64 例 $4.0 \%$ だった. 年代別に みると 60 歳代で最も頻度が高く, $6.3 \%$ に認められ高齢 になるに従い減少した. Kaplan-Meier 法にて予後を 検討すると平均余命が長いはずの60歳代が最も不良 だった，基礎疾患は，脳血管障害が $45.3 \%$ と有意に高 頻度に認められ，特に剖検例で脳梗塞を認めた例は $70.5 \%$ と多かった。 そこで動脈硬化症と EC との関係 を検討する目的で, 脳底動脈の動脈硬化の有無を調查 乙得た709例を対象として入院時 $\mathrm{Hb}$ 值と脳底動脈硬 化度とを比較した。 $\mathrm{Hb} 11 \mathrm{~g} / \mathrm{d} l$ 未満を負血群, $11 \mathrm{~g} / \mathrm{d} l$ 以上 $16 \mathrm{~g} / \mathrm{d} l$ 未満を正常群, $16 \mathrm{~g} / \mathrm{d} l$ 以上を $\mathrm{EC}$ とし動 脈硬化がないか軽微な群を第 1 群，中等度以上の群を 第 2 群とすると，表に示したように EC は第 1 群では $2.3 \%$, 第 2 群では $5.6 \%$ と動脈硬化が強い群に多かっ た。 $2 \times 3$ の $x^{2-}$ 検定でも $1 \%$ の危険率で, 第 2 群に $\mathrm{EC}$ が多く認められた。次に年代別に動脈硬化をみる と, 第 2 群の頻度は 60 代 $26.1 \% ， 70$ 代 $42.0 \% 80$ 歳以上 $58.3 \%$ と加齢と共に増加したが，第 2 群での $\mathrm{EC}$ 発現 の割合は，60代 $14.3 \% ， 70$ 代 $6.9 \% ， 80$ 歳以上 $2.3 \%$ と, 逆に若年層に多かった。この成績は，老年者のうち比 較的若い年代に多いEC の発現に，動脈硬化が何らか の役割を有する可能性を示唆すると考光られ，60年代 の $\mathrm{EC}$ 例は予後が悪いことと併せて考劣ると，興味あ る所見と思われた。

\section{1. 高齢者白血病及び Myelodysplastic syndrome （MDS）に対する Ara-C 少量療法の検討} 東京医大老年科

久保 秀樹, 佐藤 慶仁, 新 弘一 宮本 佳則, 鶴見 信男, 勝沼 英宇

目的：近年, 急性白血病の治療は, 強力な多剂併用 化学療法により高い寬解率が得られるようになった。 しかし, 高齢者白血病や, FAB 分類で Myelodysplastic syndrome (MDS) に分類される疾患の治療は, 副 作用の点で強力な化学療法の適応となり難く，有効な 治療法の確立が望まれている。今回我々は，これらの 症例に Ara-C 少量治療を施行し，その臨床効果を検討 したので報告する。

対象括よび方法：対象症例は AML $\left(M_{1}\right) 2$ 例 RAEB-T 2 例, CMML, RAEB 各 1 例の計 6 例で, 年齢は59歳から78歳, 平均68.5歳で全例男性である. Ara-C 少量治療は, 症例により $5 \sim 14 \mathrm{mg} /$ body を 12 時 間毎に連日皮下注投与し，投与期間は 1 クール 7 14 
日間とした。

結論：高齢者白血病 2 例, MDS 4 例の計 6 例に Ara-C 少量治療法を施行し, RAEB-T の 2 例に各々完 全寛解と部分寛解が得られたが，他の 4 例は無効で あった。治療後 5 例に沉血球減少がみられ, cytotoxic な効果が示唆された. 分化誘導効果については, 今回 の我々の治療経験からは, 積極的な根拠となりらる知 見は得られなかった。 副作用については感染, 出血傾 向, 貧血の増悪がみられ, 十分な補助療法が必要と考 えられた。

292. 老年者における ${ }^{111} \ln$ 標識血小板によるシンチ グラフィーの臨床的有用性の検討

都老人医療センター核医学放射線部 永島 淳一, 西野 英男, 山片 敦 丹野 宗彦, 千葉 一夫, 山田 英夫

我々は老年者に拈ける ${ }^{111} \ln$ 標識血小板によるシン チグラフィーの臨床的有用性を検討した。 血栓シンチ グラフィーを施行した 34 例, 平均年齢74歳のらち, 22 例（27件） $64.7 \%$ に異常集積を認めた。病変部位は, 心腔内 6 例, 骨盤腔内 6 例, 大動脈 10 例, 頸動脈 2 例 及び下肢静脈 3 例であった。このうち臨床的に血栓の 予測される部位以外に11例12箇所の集積像が認めら れ, その内訳は腹部大動脈瘤 3 , 胸部大動脈瘤 3 , 腸 骨動脈部 2 , 骨盤部 1 , 頸動脈部 1 , 心腔内 1 , 下肢 部 1 であり, いずれも動脈瘤, 動脈硬化巣あるいは下 肢静脈血栓症の存在が疑われた。血小板の標識に関し て, 全体では回収率, 標識率, purity はそれぞれ81.4土 $16.6 \%, 67.2 \pm 11.6 \%, 96.0 \pm 4.3 \%$ あっった. 末梢血 小板数 15 万 $/ \mathrm{mm}^{3}$ 以上と未満の 2 群間の比較では, 回 収率, 標識率に技いては有意差 $(\mathrm{p}<0.01, \mathrm{p}<0.05)$ を認めたが, purityでは差は認められなかった。しか し, 血小板数 15 万 $/ \mathrm{mm}^{3}$ 末満の群においても, 血栓イ メージングは影響を受けなかった。血小板寿命より，

Linear decay type と Exponential decay type に分け て, 血小板寿命との関係を検討した結果, Exponential decay typeでは血小板寿命は9.0日, Linear decay type は9.7日と有意の差 $(\mathrm{p}<0.05)$ を認めた。しかし， 集積の有無と血小板寿命に抢いては差は認められな かった。老年者に掻いて, ${ }^{111} \mathrm{In}$ 標識血小板による血栓 シンチグラフィーは, 予測されない血栓あるいは動脈 硬化巣を事前に知る上で良い方法であり，また下肢静 脈血栓の検出に打いても, ${ }^{111} \mathrm{In}$ 標識血小板による血栓 シンチグラフィーは十分に価値ある検査法の一つと言
える。

\section{3. 老年動脈硬化性疾患患者における血小板凝集能 の長期間観察による評価}

弘前大第二内科

金沢 武道, 井沢 和弘, 長内 智宏

金子 宏彦, 星 克樹, 今田 慶行

上村 継道, 小松修, 小野寺庚午

黎明郷リハビリテーション病院

目時 弘文, 嶋中 義人

川原 礼子, 大池弥三郎

\section{村上病院}

相馬 芳則, 花田 繁子, 村上 正一

目的：動脈硬化性疾患では血小板凝集能を度々測定 するが，測定值が種々の条件で変化することから評価 は必ずしも一定していない。われわれは血小板凝集能 がどのように変動するかを長期に観察し検討した。

対像は65歳以上の入院患者であるが，1年間に血小 板凝集能を 5 回以上測定し, 凝集能に影響を及ぼすと されている薬剤を服用していない49名である。対象の 病名は種々であるが, 虚血性心疾患, 脳血管障害, 高 血圧, 閉塞性動脈硬化症ならびに糖尿病等である。

方法：1）血小板凝集能は Aggregometerにより $\mathrm{ADP} 4 \mu \mathrm{M} / l$, collagen (CO) $2 \mu \mathrm{g} / \mathrm{m} l$ ならびに epinephrine (EP) $2 \mu \mathrm{g} / \mathrm{m} l$ を使用して測定された。 2) 採血 は午前 9 時〜11時までの空腹時に，また，血小板多血 浆ならびに乏血小板血浆の分離は型の如く行なった。

3）血小板凝集能は最大凝集率で示した.

結果：1）各対象について 5 回以上の血小板凝集能 の平均值 \pm S.D. を算出し, $\mathrm{ADP}, \mathrm{CO}, \mathrm{EP}$ の相互間で 比較し，それぞれの間での有意差の有無により種々の 型に分類した。血小板凝集能が i ) $\mathrm{ADP} \fallingdotseq \mathrm{CO} \fallingdotseq \mathrm{EP}$ の ものは18名, ii ) $\mathrm{ADP} \fallingdotseq \mathrm{CO}>\mathrm{EP}$ ののは 2 名, iii） $\mathrm{ADP}>\mathrm{CO} \fallingdotseq \mathrm{EP}$ のものは 6 名, iv $\mathrm{ADP}<\mathrm{CO} \doteqdot \mathrm{EP}$ の ものは 1 名, v ) $\mathrm{CO}>\mathrm{ADP} \fallingdotseq \mathrm{EP}$ のものは 8 名, vi） $\mathrm{CO}>\mathrm{ADP}>\mathrm{EP}$ のものは 6 名, vii) i ) 〜 vi）までの 組合せを重複して示したものは 8 名,であった。 2) 49 例中 41 例の $83.7 \%$ に抒いて， 1 年間に 5 回以上測定し た長期観察では血小板凝集のパターンは同じであっ た。

結語：1）老年動脈硬化性疾患患者を, 入院という比 較的ストレスのない状況に打くと，血小板は $7 \sim 10$ 日 で産生・破壊を繰り返しているにもかかわらず，その 大方の血小板凝集能はほぼ一定である。2）epine- 
phrine による血小板凝集能だけが単独高いものはな かった.

294. 高齢者における死亡直前の血小板数の推移 一フィブリノペプタイド $\mathbf{A}$ の変動と関連して

西武口イヤル病院

\section{廣瀬 昌代，福岡 正裕} 大山 伸樹, 角岡 東光

聖マリアンナ医大第二内科＼cjkstart渡辺勇四郎 帝京大第二外科 三石 績

目的：老齢者が，いわゆる老衰とか，心不全・呼吸 不全などによって死期を迎えつつある場合の血中環境 について，ことに血小板数扝よび thrombin生成の程 度を把握しらるフィブリノペプタイド A（以下 FPA と略す）の態度について，興味ある傾向が観察された ので若干の考察を加えて報告したい。

対象：過去 5 年間でいわゆる老衰，心不全・呼吸不 全で死亡した 530 例に打いて血小板をまた最近 4 カ月 間で同様に死亡した18例で血小板と FPA 值の推移に ついて観察した.

方法：血小板数は，電気蛍光検出方式によって，ま た FAP は, RIA-PEG 法によって測定し，結果の統計 評価は student の $\mathrm{t}$-test によった。

結果：過去 5 年間で，小わゆる老衰，心不全・呼吸 不全によって死亡した530例中, 死亡直前の血小板数が 12万以下であったのは75例（14.2\%）であり，血液学 的背景には幾多のファクターがあるにせよ血小板数が 単純に 12 万以下となってから死亡までの期間をみてみ ると平均 31 日であった。ささらに最近 4 カ月間で同様の 情況で死亡した 18 例中の半数の血小板数が12万以下で これらの死亡までの平均日数は55日であった。な打死 亡直前の FPA 值と血小板との間には，何ら関連は認 められなかった。

考察：高齢者に打いて，血小板数が減少し始めると いら徵候は，そのメカニズムは不詳であるが，全身状 態の悪化を示唆する何らかの表現であるかもしれな い，といらこれまでのわれわれの想定に対する今回の 調查で, retrospectiveには $14.2 \%$, prospeciveには $50 \%$ といら結果を得た。血小板数が減少したこれらの 症例の骨髄像では，異常は認められなかった。 FPA は 各種病態下で高値となることが知られているが，血小 板が著減していながら, FPA が高値を示さない症例も あったことから mild な D.I.C. 類似状態だとみること もできる。

\section{5．過酸化脂質と血液凝固に関する研究}

\section{名大老年科}

安藤富士子, 早川 道彦, 葛谷 文男

目的：従来より動脈硬化の促進因子の 1 つとして過 酸化脂質の存在が挙げられているが，過酸化脂質と凝 固異常との関係に関しては余り研究されていない。最 近 Gray らにより Arachidonic Acid Peroxide(AAP) の Antithrombin III（AT-III）活性に対する影響が報 告されており，我々はこれを含む数種の過酸化物の AT-III 活性预よび proteinC (PC) 活性に与兄る影響を 観察した。

方法：Cumene Hydroperoxide (CHP), Tetraethoxypropane (TEP), AAP, Linoleic Acid Peroxide (LAP) を正常ヒト血浆に添加し，そのAT-III 活性㧈 よび PC 活性に与える影響を合成基質法によって測定 した。

結果：(1) CHP と TEP は $1 \mu \mathrm{M}$ 以下の濃度で AT-III 活性をそれぞれ $37 \%$ 执よび16\%抑制した。（2） AAP は約 $10 \mu \mathrm{M}$ で AT-III 活性を $26 \%$ 抑制した。（3） LAP $100 \mu \mathrm{M}$ 以上の高濃度でも AT-III 活性に影響 を与兄なかった。（4）CHP，TEP，AAPではAT-III 活性を抑制する濃度に拈いてはPC 活性を抑制しな かった.

結論：過酸化脂質および過酸化物の存在により，血 液の性状が過凝固に傾く可能性が認められた。脳梗 塞・糖尿病などに拈いて従来より全身および局所の過 酸化脂質の上昇が報告されて抢.り，今回の我々の研究 結果と合わせて考学ると，これら過酸化脂質の増加が AT-III 活性の抑制を介して，一層凝固性を高める結 果，障害を増悪させる可能性が考えられる。またその 過酸化脂質の種類により AT-III 活性の抑制度が異な ることを考学ると，今後動脈硬化症の発症予防・治療 を考学る上で総過酸化脂質量のみならずその構成成分 の分折も必要と思われるので報告した。

296. 血小板機能および新しい凝固系測定法による高 齢者 Pacemaker 植込み例における検討

駿河台日大病院循環器科

小笠原芳宏, 八木 洋, 山崎 亨 楠本 保, 鈴木 秀夫, 杉野 敬一 渡辺 高祥, 和田 照, 杉本 賢治 佐々木樹郎, 梶原 長雄

日大第二生理柴進 
目的：65歳以上の高齢者 Pacemaker 植込み患者に おいて, 新しい測定法である FDP Ddimer 法および, 前回報告した FDP Eneo 法などを用い凝血学的検討 を行なった。

対象・方法：男 5 例女 9 例，65 80歳，植込久期間 $7 \sim 80$ 力月(平均35力月) で, 4 日以上の休薬期日を設 け，型のごとく採血した。全例に肺シンチグラム, 静 脈造影を実施した。

成績: 血小板数は全例正常範囲内で $21.7 \pm 1.5$ 万/ $\mathrm{mm}^{3}$ (mean土S.E.)であり, $\beta \mathrm{TG}(85.4 \pm 17.3 \mathrm{ng} / \mathrm{m} l)$ は14例中 8 例, $\mathrm{PF} 4(26.5 \pm 7 \mathrm{ng} / \mathrm{m} l)$ は 6 例に高值を 認めた. $\mathrm{TXB}_{2}(41 \pm 7.9 \mathrm{pg} / \mathrm{m} l)$ は全例正常内であっ た. fibrinogen $(243 \pm 14 \mathrm{mg} / \mathrm{d} l)$ は 3 例に低值を認め たが FPA (31.8 $20 \mathrm{ng} / \mathrm{m} l)$ は 7 例に高值を認めた。

FDP Latex 法では 3 例に高值を認めた. fibrin 由来分 解産物である Ddimer の測定では183土26ng/m $l$ であ り, 7 例に高値を認めた. fibrinogen 由来 $\mathrm{E}$ 分画新抗 原（FDP Eneo）の測定においては全例が正常 (10ng/ $\mathrm{m} l$ 以下)以上で $50 \pm 9.9 \mathrm{ng} / \mathrm{m} l$ であった. APTT, PT 值はいずれも正常内であった，静脈造影では全例に血 管狭窄が認められた。軽度狭窄例は 3 例であり, 高度 狭窄〜完全閉塞11例ではPF4 值において有意な高值 を示した. 血栓存在11例は, 非血栓 3 例に比し Ddimer 值に高值を認めた. 肺シンチグラムにおいて 1 例に肺 梗塞を認めた。本例では他に脳梗塞, 下肢閉塞性動脈 硬化症の合併があった。

まとめ：静脈血栓を end point として感受性, 特異 性について検討すると, Ddimer, Eneo, FPA の 3 者 の組み合わせが Pacemaker 植込又例に打ける凝血学 的経過観察には有用と思われた。なお FDP Latex 法 の感受性は低く, $\mathrm{TXB}_{2}$ 值は $\beta \mathrm{TG}, \mathrm{PF} 4$ の増加例にお いても明らかな変動は観察されず，末梢静脈血におけ る測定上の問題が考慮された。いずれにせよ高齢者に おける Pacemaker 植込みは, 植込み期間に関係なく, 高頻度に静脈血栓, 狭窄を合併し重篤な肺梗塞を併ら 症例もあり, 脳梗塞の予防といら立場からだけでなく, 抗凝固療法の必要性が考慮された。

\section{7. 大腿骨頸部外側骨折に対する Compression}

\section{Hip Screw 法について}

都老人医療センター整形外科

軽部 俊二, 五十嵐三都男, 織田 弘美 北見 圭司, 井上茂

同リハビリ部

林漛史
目的：大腿骨頸部外側骨折は本来骨癒合の良い骨折 であるが，出血が多く，疼痛が強くあらゆる体動が制 限され全身に与学影響が大きい. 強固な内固定を 行って早期離床がはかられる。当科では開院当初より Jewett nailplate 固定術を行ってきたが, penetration や cutting-outといった合併症のため昭和54年11月よ り compression hip screw (CHS) 固定術に変更して ほぼ満足のいく結果を得ている。しかし骨の脆弱な高 齢者に全く問題がない訳ではない. 当科で行って CHS 固定術症例を検討しその問題点を報告する.

方法：昭和 61 年 4 月に術後 9 カ月を超えた CHS 固 定術施行症例は304例で, 男59例, 女245例, 平均年歯 は79.8歳であった，骨折型は転子部骨折が304例中 274

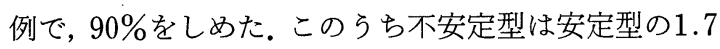
倍であった。れらの症例の術後成績につき検討した.

結果：CHS 術後の合併症は再手術を要した13例と 再手術には到らなかったが骨折部で過度の impaction をきたし疼痛のため後療法の遅延をもたらした10例で あった。再手術例は遅発性感染 1 例, non-union 又は delayed union 7 例, 内側骨折 5 例であった. 感染例は 術後 1 年半後に特に原因なく発症し, CHS 抜去後鎮静 した. non union 又は delayed union 7 例の内訳は整 復が困難であり骨癒合が得られなかったもの 1 例, lag screw の位置が悪く骨頭が内反し lag screw が cutting-out したもの 5 例, lag screw が短かすぎて骨 頭が内反したもの 1 例であった。再手術方法はCHS 固定術のやりな扎乙快人工骨頭置換術であった. CHS 術後の内側骨折は外傷やテクニカルェラーより も骨の脆弱性に問題があると考えられた，人工骨頭置 換術を全例に行った。過度の Impactionを来した症例 は10例で penetration や cutting-out を来さず全例に 骨癒合をみたが, 疼痛のため後療法の遅延, 歩行能力 の低下がみられた。

\section{8. 成人健康調査固定集団における椎体圧迫骨折の 発症率についての検討 \\ 放射線影響研究所 \\ 藤原佐枝子, 越智 義道, 佐々木英夫 大内田敏行, 細田裕}

目的：椎体圧迫骨折の発症率に及ぼす年歯, 性, 地 域差, 放射線被曝の影響, コホート効果について検討 した。

方法：ABCC-放影研では, 広島, 長崎両市で, 1958 年以来，原爆被爆者とその対照者からなる固定集団に 
ついて 2 年毎に検診を行っている。今回の解折は1958 年 7 月 1 日から 1985 年 2 月 28 日严でに 2 回以上 $X$ 線 検查を受けた 12,089 名について行い,この中から847名 の圧迫骨析の発症が確認された。解折方法はコックス 回帰分折あるいはポアソン回帰分析を用いた。

結果 : 全期間, 全年齢に招いて圧迫骨折の発症率は, 女性は男性に比べ約1.6倍高かった。地域では長崎は広 島に比べ約1.2倍高く,その差はいづれも統計的に有意 であった。放射線被曝による影響は認められなかった。 各年齢群で発症率を検討すると, 1,000 人年につき 40 歳 代で男 1.4 人，女 0.9 人， 50 歳代で男 3.2 人，女 3.1 人， 60 歳代で男 6.5 人, 女 10.2 人, 70 歳代で男 11.9 人, 女 23.5 人, 80 歳代で男 19.0 人，女 42.8 人で，圧迫骨折の発生 率は年齢に伴い増加した。また，40歳代まで男性の発 症率は女性のそれより高いが，50～60歳前後を境とし て女性の発症率が男性のそれを上まわった。コホート 効果は, 被爆時年齢を $0 \sim 9,10 \sim 19,20 \sim 29,30 \sim 39$, $40 \sim 49,50$ 歳以上の各年齢群に分け，之の各群の 40 歳 代, 50 歳代, 60 歳代, 70 歳代における発症率を求めた。 男女いづれもコホート効果をらかがわせる傾向が見ら れた。すなわち同じ年龄で発症率を比較すると，被爆 時に高齢である程, 発症率は増加し, この増加は統計 的に有意であった。

\section{9. 変形性膝関節症と慢性関節リウマチにおける 2 , 3 の酸素変動}

愛知医大第一内科

伊藤 担道, 斉藤 征夫
加藤 克己, 沢木 偆二

目的：高齢者に扮いて，関節疾患は重要な疾患であ る。関節疾患は老化をはじめ, 種々の原因によって生 じる、今回我々は, 変性疾患の代表である変形性膝関 節症 (OA), 又自己免疫疾患である慢性関節リウマチ （RA）を用いて，免疫系に関与しているプリン代謝酵 素である $\mathrm{ADA}$ (EC 3. 5.4.4., chrom. 14), PNP(EC 2.4.2.1., chrom. 14), 炎症, 免疫等に関与している SOD (EC 1.15.1.1., chrom. 21，6）に関して追求し た.

方法：1. ADA, PNP 活性測定. ADA 活性測定は, adenosine $1 \mathrm{mg}$, PNP $200 \mathrm{mU}$, XOD $200 \mathrm{mU}$, INT $0.4 \mathrm{mg}$ を $0.1 \mathrm{M}$ リン酸緩衝液 $(\mathrm{pH} 7.5) 3.5 \mathrm{~m} l$ に溶解 したものを基質溶液とし， 5 分間予備加温を行い, つ いで検体を加光, $37^{\circ} \mathrm{C} 30$ 分反応後, 反応を停止させ, 波長 $500 \mathrm{~nm}$ に打ける盲検との吸光度差を測定した。
PNP 活性測定は, inosine 1mg, XOD 200mU, INT $0.4 \mathrm{mg}$ を $0.1 \mathrm{M}$ リン酸緩衝液 $(\mathrm{pH} 7.5) 3.5 \mathrm{~m} l$ に溶解 したものを基質溶液とし，以下は $\mathrm{ADA}$ 活性と同様の 操作である. ADA，PNP活性はともに，1分間に1 umole $の$ hypoxanthine を生成する量を1IU とした。

2. $\mathrm{Cu}, \mathrm{Zn}-\mathrm{SOD}$ 活性測定. ヒト $\mathrm{Cu}, \mathrm{Zn}-\mathrm{SOD}$ に対 する mouse $\mathrm{IgG}_{1}$ 型モノクロナール抗体 $\mathrm{S}_{5}, \mathrm{~S}_{8}$ を作製 し, $\mathrm{S}_{8}$ 及び peroxidase で標識した $\mathrm{S}_{5}$ を用いた 2 抗体 ELISA 法にて Cu，Zn-SOD 活性を測定した。

結果：血清 ADA 活性値, PNP 活性値は, RA, OA に扔いて有意差を認めなかった。しかし RA に扔いて 血清 $\mathrm{Cu}, \mathrm{Zn}-\mathrm{SOD}$ 值は有意に高值を示した. 関節液に 颃いて, ADA 活性値, PNP 活性值, $\mathrm{Cu}, \mathrm{Zn}-\mathrm{SOD}$ 活 性值はいずれも OA に対し RA は有意に高值を示し た。これらのことは, 炎症疾患, 変性疾患の診断に対 し有効であると考兄られる。

\section{0. 定量的に CT 法による椎体骨密度の測定と年齢} 的変化

\section{葛城病院 \\ 坂本 千城, 坂本 洋子, 宮本 治子 山岡寿美子, 三浦 治子, 松河一主功 神戸大第三内科 藤田 拓男, 藤井 芳夫} 骨の加齢に伴う減少は普遍的な現象であり，長管骨 の皮質巾やミクロデンシトメトリー (MD) 法が行われ ているが骨粗鬆症のもっとも重要な臨床症状は腰痛で あり, 脊推の圧迫骨折がその主要病変であることを考 えると, 脊推の骨密度の測定の重要性は明らかである. しかし乍らシングルフォトンによる骨鉱質測定は前腕 骨にしか応用できず，デュアルフォトン吸収測定装置 は未だ本邦では実用化していない，CT 法は脊推の測 定部位を正確に選定し得るが電圧や条件の変化による 測定值の変動が問題であるので Genant 等によって作 製されたファントムを用いて $\mathrm{KH}_{2} \mathrm{PO}_{4}$ 相当量として 表現することをこころみた，葛城病院に入院中の50歳 から90歳までの老年者 46 人について $\mathrm{L}_{2} \cdot \mathrm{L}_{4}$ の推体につ いて皮質を含まない関心領域を設定し切片厚 $1 \mathrm{~cm}$ の CT 数を測定, $50 \sim 200 \mathrm{mg} / \mathrm{ml}$ の $\mathrm{KH}_{2} \mathrm{PO}_{4}$ 溶液を含む ファントムの同様な測定によって得られた標準曲線と 比較して $\mathrm{KH}_{2} \mathrm{PO}_{4}$ 標準液相当量として鉱質量を表現 した。切片は栄養孔を通る上下の関節面に平行な面で その略中央のものを用い, 推体に圧迫骨折その他の変 形のある場合には隣接腰推を用いた。

腰推推体の鉱質密度は $\mathrm{KH}_{2} \mathrm{PO}_{4}$ 相当量として 150 か 
ら50まで加合とともに急速に下降し，その下降勾配は 皮質骨のそれよりも大きく，女子は男子より低值であ り，又脊推圧迫骨折を示すものでは示さないものに比 ベて明らかに低值を示し, $100 \mathrm{mg} / \mathrm{d} l$ 以下のものでは 大部分に圧迫骨折が見られ, $100 \mathrm{mg} / \mathrm{d} l$ 以上の值を示 するのでは圧迫骨折は稀であり，CTによる方法は椎 体の圧迫に対する抵抗を判定し骨折の危険を予測する 上に有用であると考光られた。

301. ラットにおける実験的骨粗鬆症に対する $1 \alpha$ $(\mathrm{OH}) \mathrm{D}_{3}$, Eel calcitonin および両者併用療法の効果

名大第一内科 黒川 昌栄, 川久保明利
米田 正弘, 高㭇 健介
愛知医大中央臨床検查部
富田 明夫

目的：実験的骨粗鬆症ラットを用い $1 \alpha(\mathrm{OH}) \mathrm{D}_{3}$, Eel calcitonin 抢よび両者併用投与による効果を検討 した.

方法：生後 7 カ月の Wistar 系雌ラットを用い，脊 䯣偏側切断術抢よび卵巣摘出術を施行し麻瘏側後肢に 骨粗鬆症と類似の萎縮性骨変化を生じさせ，骨粗鬆症 の実験モデルとした。手術後 4 群に分け, 無治療群 $(\mathrm{N}$ 群)：8 匹，ビタミン $\mathrm{D}$ 治療群( $\mathrm{D}$ 群)：8 匹, $1 \alpha(\mathrm{OH})$ $\mathrm{D}_{3} 0.1 \mu \mathrm{g} / \mathrm{kg}$ を週 3 回経口投与, カルシトニン治療群 (CT 群)：7 7 , $\left(\mathrm{ASu}^{1.7}\right)$-eel calcitonin $5 \mathrm{unit} / \mathrm{kg}$ を 週 3 回筋注, 両者併用群（併用群）：8匹，同量の $1 \alpha$ $(\mathrm{OH}) \mathrm{D}_{3}$ と $\mathrm{CT}$ を週 3 回同時投与した. 又, sham 手術 群 $(\mathrm{S}$ 群)：6匹，背，腹部に皮切の久加光無治療で経 過を観察した。ラットは12週後, 断頭屠殺し, 採血後, 血清 $\mathrm{Ca}, \mathrm{P}, \mathrm{ALP}, \mathrm{PTH}$ ，扣よび Bone Gla Protein (BGP)を測定した. 更に, 各群の麻痺側大髄骨を摘出, Microdensito meter により骨皮質幅比（CTI）执よび $\Sigma G S / D$ を測定後, 骨乾燥重量, ash 重量, Ca, P 含量, および骨体積を測定した。

結果：血液生化学的検討. 各群間に血清 $\mathrm{Ca}, \mathrm{P}, \mathrm{ALP}$ および PTH 值に差を認めなかった。骨の代謝回転を 示す指標である血清 $\mathrm{BGp}$ 值 $(\mathrm{M} \pm \mathrm{SE})$ は, $\mathrm{S}$ 群 $28.8 \pm$ $2.9 \mathrm{ng} / \mathrm{m} l$ で手術により $\mathrm{N}$ 群 $47.2 \pm 3.8$ と有意に上昇 したが，CT 群は40.2土5.1とその上昇が抑制された。

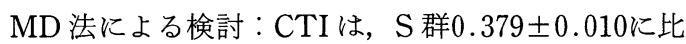
し， $\mathrm{N}$ 群 $0.342 \pm 0.001$ と有意 $(\mathrm{p}<0.005)$ に低下した が, CT 群 $0.360 \pm 0.010$, 併用群 $0.364 \pm 0.010$ と治療に より上昇を認めた。一方，骨ミネラル量を示す $\Sigma G S / D$ は各群間に差を示さなかった。

骨成分分析による検討：各群間に骨乾燥重量，骨体
積に差を認めなかった。体積あたりの ash 重量は, S 群 $691 \pm 20 \mathrm{mg} / \mathrm{cm}^{3}$ に比し, $\mathrm{N}$ 群 $594 \pm 30$ と有意 $(\mathrm{p}<0.05)$ に低下したが，D群613士42 と低下を抑制した。手術に より低下した $\mathrm{Ca}$ 含量は治療 3 群共に, 又 $\mathrm{P}$ 含量は併 用群で増加した。

結論：実験的骨粗鬆症に対し, $1 \alpha(\mathrm{OH}) \mathrm{D}_{3}$ と CT の 併用療法の有効性が示唆された。

302. アルツハイマー型老年痴呆 (SDAT) と血管性痴 呆（VD）における脸波の特徵について

東京医大老年科 南條 悦子, 勝沼 英宇 浴風会病院内科 吉田 亮一, 大友 英一

目的：痴呆の双壁であるアルッハイマー型老年痴呆 （SDAT）と血管性痴呆（VD）の生前診断の，ょり適 確さを目指する為の手段として，非侵襲性で容易に反 復検査が行なえる脳波の有用性について, 病理学的に 診断のつけられた症例のみで検討した。

方法：社会福祉法人浴風会病院に括ける連続剖検 460例中, SDAT 及びVD と診断された例のらち, 発症 時期より死亡をでの臨床経過を観察し，数回の脳波検 査を行なったものを対象とした. 各々26例, 25例であっ た。これ等の症例の病期, 重症度別に脳波の総合判定, 基礎律動及び徐波の量等について比較検討した。

結果：SDAT 及びVD の平均死亡年齢は，83.7士 6.9 歳, $78.2 \pm 7.4$ 歳で, 平均経過年数は, $7.0 \pm 3.7$ 年, $4.0 \pm 2.8$ 年. 令：古は $5: 21.9,9: 16$ となった。脳 波の総合判定で正常〜軽度異常を示した例は病初期で SDAT $85 \%$ ，VD68\%。末期は各々 $23 \%, 20 \%$ と著明に 減少した. SDATでは痴呆の進行に関連して減少して いるが, VDでは経過との関連は明らかではなかった。 次に基礎律動について SDAT では $9 \mathrm{C} / \mathrm{S}$ 以上の周波 数を示した例数は病初期から末期へ経過と共に減少し たが,VDでは経過と関連した減少は認めなかった。徐 波 $(\delta, \theta$ 波) に関しては，中等量～多量に認めた例数 の割合は，経過と関連した変化はなかった。, 又, $\theta_{2}$ 波 (6〜7C/S) そついて子，関連性は認めなかった。 $\theta_{1}$ 波 （4～5C/S）を中等量～多量に認めた例数の割合は, SDAT に打いて，痴呆の進行と関連して変動した。 波を示さなかった例数の割合も, SDAT では, 経過と 関連性を示した。以上を縓めるとSDAT では, 臨床経 過と共に脳波の変化を示したが,VDでは, 臨床経過と 脳波変化の関連は明らかではなかった。

303. 老年期前頭葉萎縮例の脳波と臨床症状について 


\section{阪和泉北病院神経内科}

林 英昭, ‘大溝 春雄

\section{阪大精神医学}

南野 壽重, 藤本 修, 西村 健

目的：CT で前頭葉萎縮を示すが，痴呆や神経学的 異常を認めず，正常脳波を示し，臨床経過や予後が良 好な症例を経験した。これらの前頭葉萎縮例は, 単純 CT のみでは両側性慢性硬膜下血腫と鑑別困難であっ た。そこで，Metrizamide CT 脳槽造影を実施し，ク モ膜下腔の髄液の交通性を検討した。クモ膜下腔との 間で髄液の交通性のない硬膜下腔の圧迫性病変である 慢性硬膜下血腫や硬膜下水腫との鑑別をこれにより 行った。この方法で前頭葉萎縮と確認した例につき， 痴呆の程度や臨床経過と脳波所見との関係について報 告し, また, 前頭葉萎縮例の病因についても検討する.

方法：阪和泉北病院の神経内科病棟敃上び老人病棟 に入院中の 1,500 例の症例により前頭部両側性に頭蓋 骨之脳実質間に $10 \mathrm{~mm}$ 以上の低 X 線吸収値域層を $\mathrm{CT}$ 像上認める20例（63～88歳）につき Metrizamide $\mathrm{CT}$ 脳槽造影を施行した。低 X 線吸収值域層, 脳溝拈 よびシルビウス裂が同時に Metrizamide で造影され， 脳萎縮のためのクモ膜下腔拡大と考学られた11例につ いて，その臨床症状を検討した。

結果：この11症例の長谷川式簡易知的機能診査ス ケールは, subnormal 以上が 5 例, predementia が 3 例, dementia が 3 例であった。 全例明確な片麻疩はな く, dementia の 3 例が寝たきり状態, predementia の 3 例中 2 例が自立で坐位保持可能，他の 6 例は独歩可 能であった. subnormal 以上の 5 例中 4 例が正常脳波 を示し， 1 例は正常 $\alpha$ 波に $\delta$ 波群発の混入する異常脳 波であった。 predementiaの 3 例は境界域から軽度異 常脳波を示し, dementiaの 3 例は異常脳波を示した。 また, 脳波基礎律動の周波数と痴呆の程度に相関 $\left(\mathrm{r}_{\mathrm{s}}=\right.$ $0.74, \mathrm{p}<0.02)$ を認めた。 predementia 打よび dementia の 6 例は血管性痴呆と診断され, subnormal 以上の 5 例にも，脳，心臓，腎臓，末梢血管等に動脈 硬化性所見を認めた。

\section{4. 老年者脳波に於けるてんかん性波型の検討 名古屋市厚生院内科}

野倉 一也, 三竹 重久, 稲垣 俊明

新美 達司, 山本 俊幸, 前田甲子郎 同生理検査 日比野純子

目的：老年発症のけいれん性疾患について脳波学的
並びに臨床的検討を試み，加えて発作はないが脳波上 てんかん性波型を呈した症例を検討した。

方法：当院に於ける659名の脳波 1,070 件のうち， 1 . 60 歳以上初発のけいれん又は意識障失発作を有し，全 身血圧低下や代謝性脳症に伴うものを除外した28例.

2. 60歳以上で発作はないが, 種々の精神神経症状を呈 し，脳波上いわゆるてんかん性波型を認めた 8 例を対 象とした。

結果：発作を有した28例の初回発作時平均年齢は 76.2 歳であり, 平均経過年数は生存例が 4.0 年, 死亡例 が 2.4 年であった. 頭部 CT 及び病理所見より原因病変 を検討すると，60歳以上といら事からか，脳腫瘍はま れで，全例中 2 例 (5.6\%) であり，脳血管障害は発作 を有した28例中 23 例 (82.1\%)，発作のない 8 例中 6 例 （75\%）と高率であった，Louisらの提唱する Early seizure, Late seizure の分類では前者が 3 例，後者が 16例，両者を認めた例が 5 例であった. Late seizure の らち発作までの平均期間は 4.4 年であった。てんかん性 波型の出現は発作のみられた28例中17例 $(60.7 \%) に$ みられ，発作型別では全般発作のみの患者で16例中 6 例（37.5\%）であったが焦点性の要素の強い発作では 10例中全例にみられた。棘波鋭波及び複合波は12例 (33.3\%)，高振幅徐波群発は 8 例 (22.2\%) PLEDs は 9 例 $(25.0 \%)$ に認め, PLEDs は老年者に出現率の高 い波型のひとつと考兄られる，発作を認めなかった 8 例は全例とも痴呆を認め, Oral tendency, 幻覚, 攻撃 性, 不随意運動など特殊な精神神経症状を呈していた。

結論：老年者脳波上のてんかん性波型は，けいれん 等の発作準備状態を示唆するとともに，異常行動や精 神症状との因果関係を含め重要な所見であると考光ら れる。

\section{5. 体性感覚誘発電位における加齢変化}

浴風会病院内科

溝口環, 吉田 亮一, 大友 英一 東大リハビリ部江藤 文夫 東大老年病 折茂

目的：体性感覚誘発電位（somatosensory evoked potential, 以下 SEP と略す)の検討には，年齡を考慮 する必要があるといわれるが，80歳以上の高齡者を対 象とした報告は少い。22歳から92歳の健常者64名を対 象として, SEP を測定した. 各頂点潜時と年齢との相 関性，および各年代に括ける潜時と身長，上肢長との 相関性を検討した。 
方法：SEP は仰臥位, 覚醒安静閉眼時に右手首の正 中神経に刺激を与光, 対側半球の手の感覚野直上の頭 皮部より導出した。刺激は, $0.2 \mathrm{msec}$ の矩形波で拇指 が軽く内転する程度の強さとし，1秒の間隔で連続的 に行った。誘発電位は, Medelec-DAV 62を使用し,

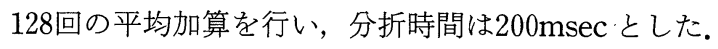

結果：(1)各頂点潜時について標準化し, 年代別に比 較すると70代，80代の各頂点潜時は他の年代に比し延 長化傾向が認められた。特に $\mathrm{N}_{1}, \mathrm{P}_{3}, \mathrm{~N}_{3}$ で著明で, 50 代の $\mathrm{N}_{1} \quad 18.5 \pm 2.9 \mathrm{msec}$ に対し 80 代 $\mathrm{N}_{1} \quad 19.8 \pm 1.2$ msec, 50 代 $\mathrm{P}_{3} 39.7 \pm 6.4 \mathrm{msec}$ に対し 80 代 $\mathrm{P}_{3} 44.5 \pm$ $4.3 \mathrm{msec}, 50$ 代 $\mathrm{N}_{3} 54.4 \pm 8.2 \mathrm{msec}$ に対し 80 代 $69.9 \pm$ $8.5 \mathrm{msec}$ と明らかな遅延が認められた. $\mathrm{N}_{1}, \mathrm{P}_{3}, \mathrm{~N}_{3}$ に おいてその潜時と年齢との間にはそれぞれ， $\mathrm{Y}=$ $14.8+0.06 \mathrm{x}$ (年齢) $(\mathrm{r}=0.41, \mathrm{p}<0.01), \mathrm{Y}=32.5+$ $0.16 \mathrm{x}(\mathrm{r}=0.42, \mathrm{p}<0.001) \mathrm{Y}=35.2+0.41 \mathrm{x}(\mathrm{r}=0.63$, $\mathrm{p}<0.001)$ といら有意な相関が得られた。 $\mathrm{P}_{1}, \mathrm{P}_{2}, \mathrm{~N}_{2}$ については一定の傾向が認められなかった。 (2)80代の $\mathrm{P}_{1}$ 潜時と身長の関係は $\mathrm{Y}=-5.36+0.13 \mathrm{x} （ \mathrm{r}=0.7$, $\mathrm{p}<0.02)$ で，60代では $\mathrm{Y}=1.33+0.07 \mathrm{x}(\mathrm{r}=0.61, \mathrm{p}<$ 0.02 と正の相関が認められた。

結語：頂点潜時は年齢とともに遅延する傾向が認め られ，特に $\mathrm{N}_{1}, \mathrm{P}_{3}, \mathrm{~N}_{3}$ に打いてその潜時と年齢との間 には有意な相関があることが認められた。これは，加 齢による伝導路の全般的機能低下，㧊よび大脳皮質の 刺激興奮性の低下を反映しているものと考兄られる。

\section{7. 老年者交感神経節における Lewy 小体出現例 の臨床病理学的検討}

都老人医療センター

$\begin{array}{lrr}\text { 東大脳研病理 } & \text { 河崎 博, 嶋田 } \begin{array}{r}\text { 裕之 } \\ \text { 朝長 }\end{array} \text { 正徳 }\end{array}$

非パーキソン病者76例の交感神経節 (上頸, 星状及 び腹腔神経節）を組織学的に観察したところ，8例に Lewy 小体の出現を認めた。 その内訳は，男42例中 5 例，女34例中 3 例であり，年齢別では 40 歳代なし（全 体数 1 例)，60歳代なし（ 7 例)，70歳代 5 例 (33例), 80 歳代 2 例 (28例)，90歳代 1 例（8例）であった。臨 床診断との関連では, 糖尿病 1 例 (同病10例中), 高血 圧 6 例 (36例), 癌 5 例 (35例), 痴呆 2 例 (21例) で あった。

交感神経節の Lewy 小体の出現と中枢神経のそれ を, 中枢神経系の検索が可能であった62例で調べたと ころ, 交感神経節の Lewy 小体の出現頻度は迷走神経
背側核の 8 例についで高かった。な括，交感神経節の らちでは圧倒的に星状神経節に Lewy 小体の出現頻 度が高かった。つぎに,末梢交感神経節に拈ける Lewy 小体出現例の臨床所見との関連をみた。1 例に経過中 静止時振戦を認めたが, 他の症例にはパーキンソン症 状がみられなかった，起立性低血圧の記載のあったも のはなく，少なくとも明らかな臨床症状はなかったと 思われる。逆に高血圧の記載のあったものが 8 例中 6 例あり，乙かもそのうち 3 例は以前高血圧があったも ののその後正常血圧になったものであった．神経症状 を含めその他の臨床所見に共通のものはみいだされな かった。

以上の結果より, 交感神経節の Lewy 小体はパーキ ンソン病に限らず老年者ではかなり高率に出現するこ と，また，Lewy 小体は中枢，末梢神経系を問わず自律 神経核に出現頻度が高く, すべて同様の機序で生ずる ことが推測された。 また，交感神経節における Lewy 小体出現例に高血圧が高頻度にみられたが，その意義 についてはさらに検索が必要と思われた。

\section{8. 老年者における Onuf 核ニューロンの定量的検} 討

都老人医療センター神経内科 布施 滋, 葛原 茂樹
山之内

都老人総合研臨床病理吉村 正博

はじめに：仙髄 Onuf 核は外肛門括約筋を支配する とされて拉り, 末期まで括約筋障害を示さない筋萎縮 性側索硬化症ではよく保たれているのに対し, 早期か ら括約笳障害がみられる Shy-Drager 症候群では, 周 囲の前角細胞がよく保たれているのとは対照的に Onuf 核のみが脱落することが知られている。しかしな がらこのニューロンの脱落の有無を論ずる場合に基礎 となる正常老年者の Onuf 核に, 若年者のそれと比較 してどの程度加齢による変化がみられるかは, 今まで あまり注目されていなかった。そこで今回われわれは 老年者における Onuf 核ニューロンの定量的検討を行 い, 加齢に伴う変化がごの程度であるかを検討した。

方法：当院剖検例より，脊髄を採取してあり明らか な脊䯣疾患がなかった72歳から95歳をでの症例 9 例 （男性 6 例, 女性 3 例)を選び, その仙髄のパラフィン 包埋連続切片を作製した。切片は厚さ $10 \mu$ とし,これに Klüver Barrera染色を施して10枚打きに Onuf核の 全景を含むように顕微鏡撮影を行った。これを印画紙 
に約300倍に焼きつけ，核小体が明瞭に認められる ニューロンを対象として, Kontron 画像解析装置を用 いて面積を測定した。

結果：男性では加齢に伴う断面積の減少は明らかで はなかった，女性は症例が限られていたが，この範囲 内では減少の傾向が認められた。ニューロンの絶対数 は, 全Onuf 核を連続切片にしえなかったので, 具体的 には算出できなかったが，その指標として 1 切片あた クのニューロン数を計算したところ, 加龄に伴い減少 する傾向が認められた。

考案：今回の検討では, 加齢に伴らニューロンの断 面積の変化には明らかな傾向は認められなかった。 72 歳の症例で既に大型の神経細胞の減少が認められてお り，その後の断面積の変化はあまり著明ではない可能 性も考劣られた。これに対して, 絶対数は加龄に伴っ て減少していく可能性が推定された。

\section{9. 老年者における小脳加齢性萎縮の病理学的検討} 島根医大第三内科

下手 公一, 小林 祥泰, 木谷 光博 山下 一也, 村田 昭博, 藤原 茂芳

恒松徳五郎

東大脳研病理

都老人総合研臨木病理

朝長 正徳

都老人医療センター神経内科

葛原 茂樹, 山之内 博

目的：加齢に伴い大脳萎縮が進行し, 大脳の神経細 胞が減少することはよく知られている。一方, 小脳に 抢いても，CTによる小脳の加齢性萎縮に関する検討 もいくつか報告されていて，すでに我々も，CTを用い て正常人（20歳代～70歳代）の小脳の加齢性萎縮は大 脳に比し軽度であることを報告している，今回は，60 歳以上の老年者の剖検脳を用いて，小脳の加龄性萎縮 について検討した。

対象及び方法：東京都養育院附属病院での剖検 500 例中, 痴呆及び中枢神経系に病変を有さず, かつ, 内 分泌疾患, アルコール中毒, 抗痤攣剤使用者を除外し た60歳から102歳の老年者142例を対象とした。平均年 齢は77.8歳で, 男82例(平均77.5歳), 女60例(平均 78.3 歳）で，年代別には，60歳代31例，70歳代56例，80歳 代46例, 90 歳以上 9 例である. 脳切時に小脳虫部及び 歯状核レベルの小脳半球をコピーして，パーソナルコ ンピューターに接続した digitizer で小脳虫部, 虫部前 葉, 左右小脳半球の断面積を計測した。ささらに, 小脳
半球の一部の小葉のプルキンエ細胞数や脳重量, 小脳 重量も計測した。

結果：1）脳重量と年齢との相関係数は $\mathrm{r}=-$ $0.3288 （ \mathrm{p}<0.001 ）$ と有意の負の相関を示した. この 関係には男女差は認められなかった。 2)小脳半球断面 積と年齢との相関係数は $\mathrm{r}=-0.3755(\mathrm{p}<0.001)$ と有 意の負の相関を認め, 小脳虫部も $\mathrm{r}=-0.3013(\mathrm{p}<$ 0.001 ) と有意の負の相関を示した。虫部前葉, 小脳重 量, プルキンェ細胞数に打いても有意の負の相関を示 した。これらの関係には男女差は認められなかった。

3）小脳半球断面積と小脳半球のプルキンエ細胞数は 有意の相関を示し，小脳の加齢性萎縮とプルキンエ細 胞の加齢に伴う減少の有意の相関が認められた。4)小 脳重量, 小脳断面積, プルキンエ細胞数は, 脳重量と 有意の相関を示した。

結論：60歳以上の老年者に扮いては，大脳の加齢性 萎縮のみならず，小脳にも加齢に伴う有意の脳萎縮が 認められた。

\section{0. 健常老人と痴呆老人の CT 所見}

都老人医療センタ一核医学放射線部 西野 英男, 永島 淳一, 山片 敦 丹野 宗彦, 千葉 一夫, 山田 英夫

目的：アルッハイマー病 (AD), 老年痴呆 (SD) と 多発梗塞性痴呆 (MID) の鑑別診断に扔ける CT 所見 の役割は，主に臨床的に疑われた血管性病変を確認す る事，あるいは潜在的な血管性病変を検出する事にあ る。我々は, $\mathrm{AD}$ 打よび $\mathrm{SD}$ においては, 脳室拡大を示 す症例に打いても, PVL の発生する頻度が少ないとい う印象を得て和り，健常老人と，臨床的に SD, MID 拉 よび $\mathrm{AD}$ と診断された患者に対して頭部 CT 検查を 行い, CVDと PVLの有無について比較検討を行っ た.

方法：社会生活を行っている健常ボランティア老人 140名を対象として行った CT 検査と, 東京都老人医療 センターに入院又は外来受診し, 臨床的に, SD と診断 された患者55名, MID と診断された患者 13 名および $\mathrm{AD}$ と診断された患者 13 名の頭部 $\mathrm{CT}$ 検査について, CVDの有無とその部位掞よび PVLの有無をしらべ, 比較検討した。

結果：健常老人についても37例にCVDが認めら れ, silent stroke の存在を示唆した。 また PVLは25例 に認められた。CVD（一)のものではPVLが5\%に見 られたに過ぎなかったが，CVD（十）の群では $54 \% に$ 
PVL が認められた。同様の事は痴呆患者群にもいえ る。即ち, 臨床上 $\mathrm{AD}, \mathrm{SD}$ と診断された群に打いても それぞれ，30\%，60\%にCT上CVD が認められた。一 方, PVLは約 $60 \%$ 症例に認められた。これをCVD の有無について見ると，PVLは， CVD(十)のものに 多く，約 $80 \%$ に見られた。逆にPVLを示した症例中, CVDを伴らものは74\%であった。これらのことは，老 年者の PVL 発生に脳血管障害が関与していることを 示唆して扣り, $\operatorname{CVD}(-), \operatorname{PVL}(-)$ のものは, かな り純粋な ADないし SDAT の可能性が高いと思われ る.

\section{1. 高齢発症の筋萎縮性側索硬化症における臨床的} 特徵

都老人医療センター神経内科

松永 高志, 葛原 茂樹, 名倉 博史 山之内 博, 豊倉 康夫

目的：筋萎縮性側索硬化症 (以下 ALS と略す) は中 壮年期に好発する疾患とされ, 長野らの1977年の報告 によれば平均発生年齢は49.8歳, 70歳以上の発症はわ ずか $1.8 \%$ となっている.しかし, 近年高齢生存者の増 加に伴い, 非典型的な病態を示す高齢 ALS 患者を診 る機会がふえている。我々は高齢発症 ALS 患者の特 徵を明らかにすることを目的として臨床的に検討し た.

方法：昭和 47 年以後当院に入院し ALS と診断され た患者53例（男30例，女23例）を，60歳未満発症の A 群15例, 60 歳 69 歳発症の B 群 20 例, 70 歳以上発症の C 群18例の 3 群に分類し, 性差, 臨床症状, 検査所見な どを比較検討した。

結果：1）性差：A 群（男10, 女 5), B 群（男11, 女 9 )は男性が多いのに対し, C 群は男女各 9 例と性差 を認めなかった，2）初発症状：A 群，B群は上肢型， 下肢型が多いのに対し, C 群は球型が $44 \%$ と最も多 かった. 3）症状：入院時に中等度以上の錐体路症状を 示したものは A 群 $53 \%, B$ 群 $35 \%, C$ 群 $22 \%$ と壮年期 発症群に多かった. 随伴症状については, 膀胱直腸障 害 6 例中 4 例, 錐体外路症状 3 例すべてが C 群と高齢 発症群に多かった。痴呆は全体で $9 \%$ に, 感覚障害は 11\%に認めたが各群間に差はなかった.4）検査所見： 血清クレアチンキナーゼ高值を示したものは $\mathrm{A}$ 群 $27 \%, \mathrm{~B}$ 群 $26 \%$, C 群 $11 \%$ と高齢発症群に少ない傾向が あった。末梢神経伝導速度遅延を認めたものは $\mathrm{A}$ 群 $0, \mathrm{~B}$ 群 $33 \%$, C 群 $44 \%$ と高齢発症群に多かった. 5）罹
病期間 : 平均罹病期間は A 群 ( 6 例) 40.0力月, B 群 (13例) 29.3 力月, C 群 (11例) 19.8力月と高齢発症群 ほど罹病期間が短い傾向を認めた。

\section{2. 高齢者にみられた hypokalemic myopathy の 臨床的検討}

群馬大神経内科

田中 真, 瓦林 毅, 岡本 幸市
森松 光紀, 平井 俊策

目的：Hypokalemic myopathy（以下本症）は，す でに多くの報告があるが, 本症の原因, 症候, 検査所 見等について総括的に検討を加えた研究は少ない、私 たちは高齢者に生じた本症についてこれらの点を検討 した.

方法：本症について 1) 体内カリウム（以下 K) 含 量低下・低 $\mathrm{K}$ 血症を生じる原因が存在し，2）低 $\mathrm{K}$ 血 症に伴った軀幹・四肢近位筋優位の筋力低下を主症状 とする症候群であり，3）上記に加党, 高 CPK 血症と 筋生検で壊死・空胞化を認めれば確実である, といら 選択基準を設けた，1），2）を満たし，本症と診断する ために十分な記載のある文献例 110 および自験例 6 の 計 116 例中 65 歳以上の 24 例を対象とし65歳未満の若年 群と比較・検討した。

結果：A）65歳以上の症例の内訳は男 9 例, 女15例, 全例の $20.7 \%$ あった。 B) 原因 (症例数)は,グリチ ルリチン製剤内服（11），サイアザイド剤(9)，消化管 手術後の下痢症 (2), アルコール多飲 (1), 系統不明の 利尿剂(1)であり, 内服薬剂が原因の $87.5 \%$ 占め, 経 口摂取低下，他剤の併用，下痢，他の合併症などが発 症の誘因・背景となっていた。c）発作が反復したもの 4 例, 筋痛 7 例, 知覚異常 7 例, 麻瘏性イレウスや膀 胱直腸障害, 意識障害などの重篤な症状もみられた. 若年群に比し発症・回復とも緩徐であり機能予後の良 好でない例もあった。 D）検査所見上, 血清 $\mathrm{K}$ 值は $1.1 \sim 2.0 \mathrm{mEq} / l$ の範囲にあり, 平均 $1.53 \mathrm{mEq} / l$ で あった．血中または尿中ミオグロビン高值は 7 例に認 めた. 動脈血ガス分析では, 全例で代謝性アルカロー シスを認め, 若年群に比し酸素分圧の低下が目立った。 結論：若年群に比し高齢者では1）薬剤内服による ものが圧倒的に多い，2）発症の誘因・背景が複雑で合 併症を持つものが多い,3）症状は重篤で回復が不完全 な例も目立つ,などの特徵があった。高齢者に対して はこれらの点や高齢者の $\mathrm{K}$ 代謝の特殊性を考慮した 投薬が必要であると思われた。 


\section{3. 老年者頸椎疾患の臨床的・放射線学的検討}

都老人医療センタ一神経内科

葛原 茂樹, 山之内 博, 豊倉 康夫
同整形外科
井上 茂

目的：老年者に执いて運動・知覚の障害を生じさせ る疾患の中で, 各種頸椎疾患は頻度の高いものの 1 つ である。本研究では, 疾患の内訳, 病変部位, 臨床症 状, 治療成績について検討した。

対象と方法：過去 3 年間に, 神経症状を主訴として 当院神経内科と整形外科に入院した，60歳以上の頸椎 疾患々者44例（男25，女19，62８2歳）について, 頸 椎単純写々断層写真, ミエログラフィー, ミェロ CTな ぞの放射線学的所見, 臨床症状, 治療成績を検討した。

結果：1) 原因疾患, 変形性頸椎症23例(男/女, 11/ 12), 後縦靯带骨化症20例 (14/6), 黄靯帯石灰化症 1 例（女）であった。先天奇形として，脊椎管狭窄症を 7 例に, Klippel-Feil 症候群を 3 例に合併していた。 2) 病変部位. 主病変は $\mathrm{C}_{3}-\mathrm{C}_{6}$ の間の中一上部頸椎に存在 するものが大部分を占めた。頸椎のほぼ全長にわたる ものも少くなかったが, 下部頸椎に限局したものは少 数であった．3）臨床症状. 頻度の高い順に, 下肢深部 腱反射方進 $(91 \%)$, 疼性対麻痺 $(86 \%)$, 下肢知覚障 害 $(86 \%)$, 上肢遠位部の運動障害 $(77 \%)$, 同部の知 覚障害 $(77 \%)$, 上肢近位筋障害 $(32 \%)$, 失調歩行 (30\%), 膀胱障害 (25\%) であった。 4) 治療. 頸椎け ん引と安静だけで治療された22例中，14例（64\%）で 症状の改善を久た。春椎管拡張術や前方固定術は20例 に施行され，15例（75\%）に症状の改善をみた。

考察：臨床症状を呈する老年者の頸椎疾患の内訳 は, 变形性頸椎症と後縦勒帯骨化症がほぼ50\%づつで あった。病変部位は頸椎の中部から上部にかけてのも のが大部分であり, 頸椎下部病変が少いことが注目さ れた。臨床症状もそれに対応して, 中〜上部頸髄の㵦 節徵候や脊髄横断症状が高頻度に認められた。内科的 治療, 外科的治療とも半数以上の症例に対して有効で あり,積極的な治療を試みる価値があると考えられた。

\section{4. 高齢者頚部脊髄症に対する脊椎管拡大術}

都多摩老人医療センタ一整形外科

井上 茂

都老人医療センター整形外科

五十嵐三都男, 軽部 俊二, 織田 弘美

同神経内科葛原 茂樹
目的：高齢者の頝部脊髄症による四肢麻痺は全身状 態が良好であるにもかかわらず，寝たさりとなる疾患 の一つである。しかし今まではともすれば手術手技が 困難である事等により保存療法が主に行なわれてき た。最近になり春椎管内に操作を加えない術式である 春椎管拡大術が開発され, 手術成績も格段に上昇して きた。私達は昭和 58 年より手術侵襲を少なくするため 簡便化した脊椎管拡大術を行ってきたのでその成績を 報告する。

方法：症例は頝椎後緃勒帯骨化症11例, 頚椎症性脊 髄症 10 例, 計 21 例である。年齢は 60 歳より 82 歳, 平均 71.9 歳で, 男14例, 女 7 例であった。手術はミエログ ラフィーにて通過障害を認める範囲すべてについて行 い, 3 椎弓を拡大したもの 3 例, 4 椎弓 9 例, 5 椎弓 9 例であった。術後は 1 週間ベッド上安静をとらせ, その後硬性䅡椎固定装具をつけ行動させ, 術後 6 週以 後は軟性カラー装着にてリハビリテーションを行い, 3 力月後に装具を外して日常生活に復帰させている。

結果：ADL 上重要な歩行能の点では, 術前どのよう な方法を用いても歩行出来なかった 10 例中 9 例までが 何らかの補助用具を用いて歩行可能となった。歩行障 害を認めた20例中, 歩行形態の一段階以上の改善を見 たものは15例であり，改善しなかった 5 例は全例㾏性 又は失調性歩行ながら何とか独歩可能な症例であり, 何らかの歩容の改善は 4 例に認めている. 総合判定に より, 著明改善と認めたものは 8 例, 改善 10 例, 不変 3 例であった。乙かし不変 3 例中 2 例には自覚症状, $\mathrm{ADL}$ に何らかの改善を見でう，手術が無意味だった と思われたのは 1 例のみであった。著明に改善したと 認められた症例は発症もしくは急性増悪後 1 年以内 で, 頝椎牽引に反応したものが大部分であった。この 事はたとえ高齢者であっても，症例を選べば手術によ り脊髄機能を回復させ, 寝たきり老人の予防になる事 を示していると思われる。

\section{5. 特発性正常圧水頭症における髄液短絡術の効果} 都老人医療センター脳神経外科

$$
\text { 青柳傑, 福本 達, 布施 正明 }
$$

目的：原因の明らかでない所謂特発性正常圧水頭症 は, 高齢者に多く痴呆, 尿失禁, 歩行障害を主症状と する事から, 他の脳萎縮性疾患との鑑別が困難な場合 が少なくない，髄液短絡術の効果予測の上で, 術前の 各種検查及び所見の有用性を明らかにする事を目的と した。 
対象・方法：1977年から1985年迄の 9 年間に特発性 正常圧水頭症を疑われ腰椎腹腔短絡術を施行した 27 症 例を対象とした. 平均年齢70.1歳女 8 例男 19 例である. 術前臨床経過, CT (脳室拡大の程度, 脳溝払大, 脳室 周囲低吸収域及び小梗塞巣の有無)， RI または CT 脳 槽撮影, 䯣液吸収試験及び脳波所見を手術効果と比較 検討した。

結果：(1)手術効果は, A 著効13例， B 軽度または一 過性改善 9 例, C 無効 5 例であった. (2) Ventricle

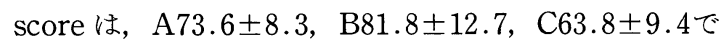
$\mathrm{A} ・ \mathrm{~B}$ 群と $\mathrm{C}$ 群では有意差を認めた。脳溝拡大は著効 例にも認められたが, Sylvius裂により拡大が著しく, 8 例で, 術後拡大した脳溝の縮小が確認された。脳室 周囲低吸収域は，著効例で高度の傾向があり，また小 梗塞巣は各群でみられ, 各々, 必ずしも十分な効果判 定基準とはなり得なかった。(3)脳槽撮影, 䯣液吸収試 験, 脳波所見とも, 各々有用な効果判定基準とはなり 得なかった. (4)先行する特有な歩行障害は, A 群12/ $13, \mathrm{~B}$ 群 $3 / 9, \mathrm{C}$ 群 $2 / 5$ と著効例に多い.

考察及び結論 : 特発性正常圧水頭症では脳溝拡大例 に沶いても，手術有効例がある。こうした例の中に， 拡大した脳溝が術後縮小寸る例があり, 髄液循環障害 によるくも膜下腔拡大のためと考兄られる. CT 上の 脳室拡大に加えて, 先行する特有な歩行障害の存在は 効果予測の上で有用である。また一般に高齢者で多く 見られる髄液循環障害及び, 脳室周囲低吸収域は必ず しも効果予測の十分な基準とはなり得ない.

\section{6. metoclopramide によるパーキンソニズム症状 の発症率と増悪率}

岡山大脳代謝研

小川 紀雄

岡山大第三内科

黒田 広生, 高山 晴彦, 太田 善介

香川県立中央病院神経内科 山本 光利

目的：一般内科で消化器症状に対して処方される metoclopramide (以下 MCPM と略す)によって， ま れではあるがパーキンソニズムを生ずるとの報告があ る.そこでMCPMによるパーキンソニズム症状の発 症率と増悪率について検討した。

方法：過去 5.5 年間に 14 日間以上の内服薬の処方を 受けた患者を調查対象とした。 また同期間にパーキン ソニズム症状を呈して来院した患者について, MCPM によって症状が悪化していたかどらかについても調べ た.
結果：過去 5.5 年間に 14 日間以上の内服薬を投与さ れた患者は, 外来患者 8,345 名(男 4,730 名, 女 3,615 名), 入院患者 1,905 名 (男 780 名，女 1,125 名) の合計 10,250 名であった.これらのうち，2 週間以上 MCPM を投与 されていた患者は，外来患者 8,345 名中 400 名 (3.9\%), 入院患者 1,905 名中 328 名 $(17.2 \%)$ で，調査対象 10,250 名中728名 (7.1\%) であった。これらの中で, MCPM によってパーキンソニズムが発症し，その中止によっ て症状が完全に消失したものは 3 名(男 1 名, 女 2 名) で, いずれも70歳以上の老年者であった，従って， MCPM 2 週間以上服用者の $0.41 \%$ に発症したことに なる。また，我々が過去 5.5 年間に診療したパーキンソ ニズム患者は184例で，そのらち，MCPMによって症 状が著しく悪化していたもの（増悪例）は，4例で， パーキンソニズム患者の $2.17 \%$ にたる.しかし， MCPMを服用していたパーキンソン病患者にわずか 16例であったので，真の症状悪化率は実に $25 \%$ とら 高率であった。増悪例もいずれも70歳以上の老年者で あった。

結論：老年者では MCPM によってパーキンソニズ ムが発症するおそれがあるので処方するのは好ましく なく，また，パーキンソン病患者ではその症状を悪化 させるので MCPM は使用すべきでない.

\section{7. パーキンソン病患者の呼吸機能の検討}

都老人医療センター神経内科

$\begin{array}{lll} & \text { 坂下 } & \text { 泰雄, 葛原 茂樹 } \\ \text { 同 呼吸器科 増山 英則, 木田 厚端 } \\ \text { 同 研究検査部 } & & \text { 米山美智子 }\end{array}$

パーキンソン病 (PD) 患者の呼吸機能执よび flowvolume curve $(\dot{\mathrm{V}}-\mathrm{V})$ の effort independent zone に おける oscilation（osc.）の出現頻度を検討した。

対象は60〜85歳の PD22例で, 平均年齢は73.7歳,

Yahr 重症度分類では I 度が 3 例, II 度が 10 例, III度が 9 例であった。全例に病歴上, 軽度から中等度の振戦, 無動, 筋固縮を認め, 明らかな呼吸器疾患や他の神経 疾患の合併はなかった。また，正常者に拉ける osc。の 出現頻度をみるために，対照群として明らかな神経疾 患や呼吸器疾患を有さない者123例をとった. PD 群と 対照群との間で年齢・身長・体重に有意差はなかった。

$\mathrm{PD}$ 患者の呼吸器機能では, 重症化につれ肺活量, 最 大換気量, ピーク・フロー, $\dot{\mathrm{V}}_{50} / \dot{\mathrm{V}}_{25}$, 一秒量の低下の 傾向がみられ, 一秒率, $\dot{\mathrm{V}}_{50}$ は変化せず, $\dot{\mathrm{V}}_{25}$ は増加の 傾向を示した。以上より重症例ほど拘束性変化が増強 
し, 瞬発力と換気の持続力が低下すると考兄られ，末

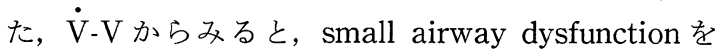
伴っているか, 拘束性変化増強に上気道閉塞パターン が加わっていると推定された。従って, PD 患者の呼吸 機能には，胸郭を形成している筋の無動や固縮，命令 に対する反応の遅さあるいは声門一喉頭部の不随意的 狭窄が影響を及ぼしている可能性がある.

振戦を有する錐体外路疾患患者では $\dot{\mathrm{V}}-\mathrm{V}$ の effort independent zone に osc. が出現することが特徵であ り，PDの50\%に osc. を認めたと報告されている (Vincken 1984). 本研究では軽度のものを含めると PD の $50 \%$ osc. を認めたが, 振戦を有さない対照群 でも $31.2 \%$ osc. の出現を認めた。 osc. を認める PD 患者 1 例で抗パーキンソン薬投与前後で osc. 出現を 比較したが, 薬物投与後臨床的に振戦は軽減したが, osc. には変化はなかった。 以上より対照群でも高率に osc. が出現したことの原因は不明であるが， osc. 出現 が PD の特徴であるとは結論できなかった。

\section{8. パーキンソン病患者における視覚を介した認 知, 記憶能の評価一その一試案}

山口大神経精神科

池田 俊美, 増本 茂樹, 山田 通夫

目的：パーキンソン病患者に扔いて大脳皮質障害に よると考光られる巣症状がいくつか認められるが，そ の中でも視覚認知括よびそれに関連した記憶の障害が 最近注目されている。そこで我々は，この障害を簡便 に評価する一つの試みとして物品拈よび人物の顔の写 真を用いたテストを実施し，その妥当性を検討した。

方法：パーキンソン病患者群 (P 群) 12例 (男 3 例, 女 9 例, 平均年齢69.0歳, Yahr : Stage I -IV), 健常 者群 (C 群) 10名 (女10名, 平均年齢68.7歳) を対象に 次のテストを実施し，2 群間の比較を行なった。 1) 10 の物品の写真を見せ記憶させた後, いくつ思い出せる か問 弓 (R-test, 各 1 点, 計10点). 2) R-test の10の各 物品と，それとょく似た物品の写真とを 2 枚示し，ぞ ちらが前の物か答党させる(D-test, 各 1 点, 計10点). 3） 1 名から 7 名 $(1 ， 2 ， 3 ， 5 ， 7$ 名) から成る顔 写真のグループを作り, 人数の少ない方から順に顔と 名前を対比させて記憶させ，その後顔写真のみを示し て名前を答光させる(F-N-test，1名：1名正答につき 1 点, 2 名：同1.5点, 3 名：同 2 点, 5 名：同 3 点, 7 名：同 4 点, 計53点). 更に $\mathrm{P}$ 群については上の 3 テ ストの得点, 年齢, 罹病期間, Yahr の重症度, 長谷川
式スケール (H-scale) の得点の各項目間の相関につい ても検討した。

結果：1）P 群はC 群と比べR-test, F-N-testに抒 いて有意に低得点であった $(\mathrm{p}<0.05)$ が，D-testでは 差が見られなかった。 2) P 群ではR-test, D-test, F-N-test の各得点と Yahr の重症度との間に負の相関 が見られ $(\mathrm{r}=-0.72 \sim-0.79), \mathrm{H}$-scale の得点と F$\mathrm{N}$-test の得点とは正の相関が認められた $(\mathrm{r}=0.70)$. 以上から $\mathrm{P}$ 病に和ける視覚認知, 記憶能力の評価に R-test, F-N-test が有用であり，また，重症になるほど その能力が強く障害されてくることが示唆された。

\section{9. 光持続時間の長短判断の研究}

\section{東京警察病院内科}

山本 雅康, 後藤 平

安達 敏彦, 吉川 政己

目的：加齢による情報処理能力の変化を知るため, 前回は前後して聴かせた 2 音の長短を比較させ音持続 時間長短認知能力が加㱓により減衰傾向を認めた。今 回は光刺激の持続時間長短判断はどのようになるかを しらべた.

方法: 脳機能正常の 20 歳, 30 歳代の被験者 9 名と 50〜70歳代の被験者 8 名を対象とした. 赤色発光ダイ オードマトリックスにランダムドットパターン (RDP) $2 \sim 4$ 回, 第 1 マーク, RDP $2 \sim 4$ 回, 第 2 マーク, RDP 2 回よりなる 1 連の発光をし視覚刺激と し，これを反復した。 RDP は65，135，165，235，265， $335 \mathrm{~ms}$ 発光のいずれかとし，第 1 ，第 2 マークは 100 , $200,300 \mathrm{~ms}$ 発光のいずれかとした。これらを1.6秒毎 に発光させ刺激とした。第 1 , 第 2 マークの組み合わ せが長短か短長か同一かを判断し，1連の刺激直後異 なったスイッチを押させ，その応答の正誤率をしらべ た.

結果：20，30代（A）でも50～70歳代 (B) でも 200, $300 \mathrm{~ms}$ の組み合わせの判断に誤答が多く誤答率は A43.1\%, B42.7\%であった. 誤答率は同一の長さの組 み合わせで A $31.9 \%, B 32.9 \%, 100,200 \mathrm{~ms}$ の組み合 わせで $\mathrm{A} 18.5 \%, \mathrm{~B} 21.9 \%, 100,300 \mathrm{~ms}$ の組久合わせ でA7.7\%, B7.6\%であった。すなわち AB ともに200, $300 \mathrm{~ms}$ の組み合わせの判断に誤答が最多で次に同一 の長さの組み合わせ, $100,200 \mathrm{~ms}$ の組み合わせ, 100 , $300 \mathrm{~ms}$ の組み合わせの順に誤答率がへり，いずれも $\mathrm{AB}$ 群に有意の差はなかった。

結論 : 光刺激でも音刺激と同様に $200,300 \mathrm{~ms}$ の組 
久合わせ，同一長さの組み合わせ，100，200ms の組み 合わせ, $100,300 \mathrm{~ms}$ の組み合わせの順に誤答率が減少 した。しかし音刺激では200, 300 ms の組み合わせに加 齢による判断能力の減衰が認められたが(既発表), 光 刺激では加龄による有意の差は認められなかった。こ れは200，300ms の長さの弁別は光刺激では $\mathrm{AB}$ 群と もに困難なためと思われる。

\section{0. 加齢による皮膚痛覚閾值の変化と脳卒中患者に おける痛覚閾值の変動に関する研究}

\section{名大老年科藤田 勝成，葛谷 文男}

目的：痛覚・触覚を客観的かつ定量的に測定できる よう我々は痛覚・触覚検査機を考案した。この検査機 を用いて痛覚の加齢による影響と脳卒中後遺症患者の 痛覚・触覚障害について検討した。

方法：痛覚検査機は棹科式で先端に 3 本のピンが直 角に取りつけられ，桿科の扮もりを移動させて皮膚に かかる負荷量を増減させるものである。これを一定の 高さから皮虐面に落下させる方法と予め皮膚面に針先 を接触せしめた後，おもりを移動して加重させる方法 とがあり，痛覚を感ずる負荷最小值（痛覚閾値）を測 定した。痛覚閾値の単位は，括もりを基準点から移動 させた距離で表示した。検査部位は左側の第 2 指，手 の背側及び掌側で，各部位の周辺 3 カ所で刺激を与兄 その中で最少のものを痛覚閾值とした。対象は 10 歳代 から70歳代までの各年代群男性 (健常) 20 名ずつ計140 名である.脳卒中患者は発作後 6 力月以上経過し痛 覚・触覚障害が固定したと思われた10例を対象とした。

結果：各年代に扮ける指背側での痛覚閾值の平均值 は加重法では10歳代で3.4, 20歳代で 3，30歳代で3.4, 40歳代で3.3，50歳代で3.4，60歳代で3.5，70歳代で 3 であり加齢による痛覚閾値の上昇は認められなかっ た。落下法では 10 歳代で0.55であり，各年代ともにば らつきが多く70歳代で 0.65 と痛覚閾值の上昇は認めら れなかった。痛覚閾值は各年代それぞれ個体差が大き いが，加重法ではほとんど 6 以下であり落下法では 1 以下であった脳卒中患者 10 名での患側での痛覚閾值は

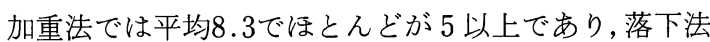

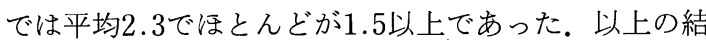
果より脳卒中患者患側では健康な対照群および患者健 側に比較して痛覚閾值の上昇が認められた。

321. 老年痴呆における cholinergic neuron の質的 変化について

\section{京大神経内科 越村 邦夫, 遠山 育夫 中村 重信, 亀山 正邦 静岡県立中央病院神経内科 加藤 智信}

目的：老年痴呆剖検脳を用いて，choline acetyltransferase (ChAT) の最大活性（Vmax）和よび基質 親和性 $(\mathrm{Km})$ を測定しさらに分子量も測定し合わせて 検討した。

方法：老年痴呆 5 例 (平均 87.4 歳), 非神経疾患の対 照 6 例 (平均83.7歳) の剖検脳より前頭葉皮質 (Brodmann 6 野）と側頭葉皮質（Brodmann 21+22野）を 採取し測定に用いた。ChAT の Vmax 抢よび Kmは， 基質中の choline または acetyl-CoA の濃度を変光, Lineweaver-Burk plotより求めた。分子量の測定はカ ラムクラマトグラフィ法括よびショ糖密度勾配遠沈法 により行った.ChAT 活性は Fonnum の方法で測定し た。

結果：Vmax は老年痴呆で有意に低下していた $\{$ 前 頭葉：老年痴呆7.52 ( $\mathrm{nmol} \mathrm{ACh} / \mathrm{min} / 100 \mathrm{mg}$ 蛋白), 対照 $10.79, \mathrm{p}<0.03$, 側頭葉: 老年痴呆 5.73 , 対照 12.46, $\mathrm{p}<0.05\}$. choline, acetyl-CoA に対する $\mathrm{Km}$ は老年痴呆でいずれも高值であった $(\mathrm{Km}$ for choline：前頭葉 ; 老年疾呆 $2.11(\mathrm{mM})$, 対照 $1.90, \mathrm{p}<$ 0.02 , 側頭葉 ; 老年痴呆 2.26 , 対照 $1.38, \mathrm{p}<0.05, \mathrm{Km}$ for acetyl-CoA : 前頭葉 ; 老年痴呆95.3 $(\mu \mathrm{M})$, 対照 $67.6, \mathrm{p}<0.01$, 側頭葉; 老年痴呆 206.8 , 対照93.3, $\mathrm{p}<0.03)$.さらに $\mathrm{Km}$ と $\operatorname{Vmax}$ の間には有意の相関 が認められた（前頭葉：Km for choline vs. Vmax $\mathrm{p}<$ $0.003, \mathrm{Km}$ for acetyl-CoA vs. Vmax $\mathrm{p}<0.009$; 側 頭葉 : Km for choline vs. Vmax, n.s., Km for acetylCoA vs. Vmax $\mathrm{p}<0.05)$. またカラムクロマトグラ フィー扣よびショ糖密度勾配遠沈法で行った ChAT の分子量の検討では，いずれの測定法でも老年痴呆で 高分子量分画に高活性を認めた。

考察：老年痴呆に扮ける ChAT の Vmax の低下は cholinergic neuron の变性消失による量的低下を反映 するものと考学られた。これに対し $\mathrm{Km} の$ 変化は acetylcholine 合成効率の低下を意味し, ChAT の質的 低下を示唆していた。また Vmax と $\mathrm{Km}$ が有意の相 関を示した点より老年痴呆に打けるChATの量的打 よび質的低下が同一因子によると考兄られた。その因 子としてChAT 蛋白の劣化が予想され, ChAT の分子 量の測定結果はこの推測を支持していた。

322.ラットの学習・記憶における脳内コリン作動性 
神経系の機能に関する研究一第 1 報一明暗箱を用いた 受動的回避反応について

$\begin{array}{lrrrr}\text { 名大老年科 } & \text { 五藤 } & \text { 勉, } & \text { 中山 } & \text { 泰一 } \\ & \text { 遠藤 } & \text { 英俊, 葛谷 } & \text { 文男 } \\ \text { 同 第三内科 } & & & \text { 井口 } & \text { 昭久 }\end{array}$

目的: Alzheimer 型老年痴呆 (SDAT) では種々の 神経伝達物質の異常が報告されているが，中でも Meynert 核から投射するコリン作動性神経系の機能 の低下は広く認められている。我々は Acetylcholine の阻害剤である Scopolamine (Scop)を第 3 脳室に植 え込んだカニューレより脳室内および腹腔内へ投与す るとともにヒトの Meynert 核に相当するラットの前 脳基底部 ( $\mathrm{BF}$ 部)を電気的に破壊することによりラッ トの学習・記憶がぞのように変化するかを明暗箱によ る受動的回避反応を用いて調べSDAT の動物モデル となりらるかを検討した。

方法：脳手術・230g 前後の Wistar 系雄性ラットを 麻酔下で脳固定装置に固定し, Pellegrino らの脳図譜 に従い第 3 脳室にステンレスカニューレを插入し歯科 用セメントで頭皮に固定した。, 又, 破壊手術はBF 部に 相当する位置に白金電極を刺入し，通電した，偽手術 ラットには同様の操作をしたが通電しなかった，受動 的回避反応・各々 $30 \times 30 \times 30 \mathrm{~cm}$ の 2 の箱の床のグ リットを通し通電できる明暗箱を用いた。ラットを明 箱に入れ四肢が暗箱へ入った時点で通電し獲得試行を 行なった. 獲得試行 1 日後に脳手術を行ない，7 日後 に脳室内及び腹腔内に Scop を投与し, BF 破壊群とと もに再生試行を行なった。

結語：獲得試行ではほぼ全例が60秒以内で暗室へ移 動し 300 秒以上要したのは 1 例もなかった. 腹腔内投与 では再生試行時 Scop の投与量に応じ潜時の短縮及び 暗箱への移動率が高まったが，脳室内投与ではみられ なかった。脳室投与の影響は脳室近傍のみと考兄られ た。 又, $\mathrm{BF}$ 破壊ラットの約半数は 300 秒以内で暗箱へ 移動したが, 偽手術群ではその割合が低く, BF 部破壊 では明らかに記憶障害を示し, SDAT モデルとしての 可能性が示唆された。

323. ラットの学習・記憶に及ぼす脳内コリン作動性 神経系の機能に関する研究一第 2 報一放射状迷路課題 について

$\begin{array}{lrrrr}\text { 名大老年科 } & \text { 中山 } & \text { 泰一, } & \text { 五藤 } & \text { 勉 } \\ & \text { 遠藤 } & \text { 英俊, 葛谷 } & \text { 文男 } \\ \text { 名大第三内科 } & & & \text { 井口 } & \text { 昭久 }\end{array}$

目的：平均寿命の延長に伴う高齢化社会の形成は, 老年疾呆の問題を深刻化している。老年痴呆の中核症 状は社会適応が不能になる程の知能低下・記憶力低下 であるが，現在その生物学的発症機序は必ずしも明ら かではない. その中で Alzheimer 型老年痴呆に招いて は脳内コリン作動性神経系の機能低下が報告されてい る. そこで我々は放射状迷路課題を学習させたラット に抗コリン作動薬 Scopolamine (Scop)を投与し, コ リン作動性神経系が記憶・学習に括いてどのような役 割りを果しているかを検討した。

方法：8 方向放射状迷路に扔いて全アームの半数に あたる奇数番号のついた 4 本にのみ置かれた報酬を得 るといら課題を習得させたラットを作製した.Scop は 腹腔内もしくは予め植光込まれたガイドカニューレを 通して第III脳室内に投与した。投与後 1 または 5 分, 60 分及び 24 時間の時点で再生試行を実施した。報酬が 置かれたアームを選択した場合を正選択, 報酬が置か れないアームや概に選択されたアームを再び選択した 場合を誤選択とし, 記憶の評価は試行時間, 最初の 4 選択中の正選択数及び全誤選択数を指標として行っ た。

結果・考察：Scop $0.01 \sim 10 \mathrm{mg} / \mathrm{kg}$ の腹腔内投与に より 5 分及び 60 分後の時点では注淁用量依存的な試行 時間の延長, 正選択数の減少, 誤選択数の増加を認め た。誤選択は偶数番号のアームを選択するより奇数番 号のアームを再度選択する場合が有意に多かった。し かしこれらの変化は投与後 24 時間の時点では投与前值 に復していた。 また $5 \times 10^{-9} \sim 5 \times 10^{-6} \mathrm{~mol} / 2 \mu l$ の Scopを第III脳室内に投与した場合にもほぼ同様の結 果を得たが，その結果は腹腔内投与の場合程著明では なかった。 今回用いた実験系では報酬の置かれたアー ムの記憶が参照記憶, ある試行で概に選択したアーム の記憶が作業記憶と考兄られる. 従って以上の結果よ りScop は作業記憶を一時的に阻害する可能性が示唆 された。

324. 老年痴呆患者における髄液および血浆アセチル コリン・エステレース アイソザイム一電気泳動法に よる検討

京大神経内科

中野 智, 中村 重信, 亀山 正邦

静岡県立総合病院神経内科 加藤 智信

目的：アルッハイマー病では, 髄液アセチルコリン・ エステレース（AChE）活性が低下し, 血浆 $\mathrm{AChE}$ 活 
性は逆に上昇しているといら報告がある。さらにそれ らの変動は, 病期によって差がある可能性も示唆され ている、AChEには, いくつかのアイソザイムの存在 が知られているが，その分析によって，痴呆疾患の初 期䛦断の可能性も考号られる, われわれは, 日常検査 として応用可能な方法である, ディスク・ゲル電気泳 動法により，髄液扣よび血浆の AChE アイソザイムを 分離した。

方法：AChE 活性は, Ellman 法により, 分光学的に 測定した。アイソザイムの分析には，ポリアクリルア ミドゲルディスク電気泳動法を用いた。泳動後の $\mathrm{AChE}$ の染色には, アセチルチオコリンを基質として 用いた。偽コリン・エステレースに特異的な阻害片と して iso-OMPAを, AChE と特異的な阻害剤として BW284C51を用いた。

結果：電気泳動後アセチルチオコリンを基質として 染色を行なった場合, 䯣液は 3 本, 血奨は 6 本のバン ドが確認できた。 iso-OMPAを加兄た染色液では, 髄 液は 1 本, 血浆は 2 本のバンドが確認でき, これらは, $\mathrm{AChE}$ のアイソザイムに相当すると考兄られた。ささら に, 染色液に BW284c51を加光た場合, ブチリルチオ コリンを基質として用いた場合についても検討した。

結論：電気泳動法によれば, 髄液 AChE は単一のア イソザイムよりなり，これは以前われわれが，ショ糖 密度勾配遠沈法, カラムクロマトグラフィーによって 確認した結果と一致する。それに対し, 血浆中には少 なくとも 2 種の $\mathrm{AChE}$ が存在する. 本法は簡便である ため，日常検查に応用可能である。

\section{5. 老年者の神経疾患患者に於ける髄液中補体, 免} 疫グロブリンの検討

$$
\begin{aligned}
& \text { 聖マリアンナ医大第三内科 } \\
& \text { 荒井 義彦, 矢崎 俊二, 平山 俊和 } \\
& \text { 高橋 洋一, 辺見 仁, 米田 直人 } \\
& \text { 原 良太郎, 染谷 一彦 }
\end{aligned}
$$

目的: 近年, 神経疾患に於ける髄液中の補体, 免疫 グロブリンの変動が注目されている、特に髄膜炎や多 発性硬化症での䯣液中補体, 免疫グロブリン值の上昇 がこれまで主に報告され，その機序としては，炎症に 伴う血液脳関門での透過性の充進が考兄られている。 また髄膜での補体の産生の充進も考吕られており, 罹 患者の免疫能の程度との関係も考劣ねばならないと思 われる.さらに高齢者では加齢に伴う免疫能の変化も, 上記の変動の機序を考える上で重要である。思われ
る、そこで我々は, 老年者の各種神経疾患患者に於い て入院中に採取された髄液で補体 $\left(\mathrm{C}_{3}, \mathrm{C}_{4}, \mathrm{CH}_{50}\right)$, 免 疫グロブリン (IgG, IgA, IgM)を測定し, 神経疾患 に於ける加齢に伴ら免疫能の变化を検討した。

方法：対象は当科に入院した各種神経疾患患者（脳 血管障害, 髄膜炎, 脳炎, 悪性腫瘍脳転移, 多発性硬 化症, Guillein-Barré 症候群，てんかん，その他)計36 症例で, これを中枢神経系に炎症を伴ら疾患群18例と, 炎症を伴わない疾患群18例に分け，さらに各々を若齢 者群 (39歳以下), 中齢者群 (40 64歳) 打よび高齢者 群（65歳以上）に分け, 中枢神経系の炎症, 加齢と免 疫能との関係を検討した。補体, 免疫グロブリンは Laser immunoassay 法で測定した。

結果: 中枢神経系に炎症を伴う疾患群では髄液中 IgG, IgA, IgM, C 4 は, 炎症を伴わない疾患群より有 意に高值を示した。髄液中 $\operatorname{IgG}, \operatorname{IgA}, \mathrm{C}_{4}$ 值は, 中枢神 経系に炎症を伴わない疾患群は加齢に伴いわずかな増 加傾向を示し, 炎症を伴う疾患群では高齢群は若齢者 群より有意に高値であった。

結語：神経疾患患者に於い, , 中枢神経系に炎症を 伴う場合は髄液中 $\operatorname{IgG}, \operatorname{IgA}, \operatorname{IgM}$ 拈よび $\mathrm{C}_{4}$ の増加が 生じ, この中枢神経系での免疫反応には炎症の種類や 程度などの他に, 加齢に伴う免疫調節機能の異常の存 在が関与している可能性が示唆された。

\section{6. 喫煙の脳血流に及ぼす影響について}

島根医大第三内科

山下一也, 小林 祥泰, 山口 修平 木谷 光博, 岡田 和悟, 村田, 昭博 恒松徳五郎

Rogers らや窪田らは, 長期にわたる泪煙は, 脳動脈 硬化を促進し, 脳血流量を減少させると報告している. しかし, 契煙による肺機能の低下の影響も無視するこ とができないと思われる。 今回, 我々は, ${ }^{133} \mathrm{Xe}$ 吸入法 によって測定した脳血流量と乫煙の関連について検討 を行なった。

対象：地域健晾対象者健常男性66名, 平均66歳で, 内訳は, 若年群 (30歳 64歳) 契煙者群 14 名, 非契煙 者群14名, 高年群 (65歳以上) 契煙者群 16 名, 非契煙 者群22名である。な扔, 契煙者とは, Smoking index が200以上の人とした.

方法：1）脳血流量測定：16ch-NOVO-cerebrograph により, ${ }^{133} \mathrm{Xe}$ 吸入法で行ない, 平均 $\mathrm{F}_{1}$ 值を用い た.2）呼吸機能：Chest 社製 Autospiror HI-498で測 
定. \%VC, FEV1.0\%, $\dot{\mathrm{V}}_{50}, \dot{\mathrm{V}}_{25}, \dot{\mathrm{V}}_{50} / \dot{\mathrm{V}}_{25}$ の各指標を用 いた。3） $\mathrm{PeCO}_{2}$ : Datex 社製 Capnograph で終末呼 気 $\mathrm{CO}_{2}$ 濃度を測定し換算.

結果：1）加齢性変化：脳血流量, $\mathrm{Ht}, \dot{\mathrm{V}}_{50}, \mathrm{PeCO}_{2}$ が年齢と有意の負相関を示した $(\mathrm{p}<0.005) .2)$ 脳血 流量と $\mathrm{PeCO}_{2}$ は有意の正相関を示した $(\mathrm{p}<0.001)$. 3）脳血流量において, 若年契煙群, 非契煙群では差は みられなかったが，高年喫煙群は，非契煙群に比し， 有意に低值であった。 4) 若年群, 高年群とも盁煙群で は, 非契煙群に比し, $\dot{\mathrm{V}}_{50}, \mathrm{PeCO}_{2}$ とも有意に低值を示 した。しかし，その他の呼吸機能に差はみられなかっ た. 5）若年群，高年群とも喫煙群，非掣煙群間で，平 均血圧， T-CHO， HDL-C, Ht， AT3に差はみられな かった。

結論：長期の契煙は潜在性の Small airway の障害 による $\mathrm{PeCO}_{2}$ の低下を介して, 脳循環に影響を及ぼし ている可能性が考兄られる。

\section{7. 健常高齢者の脳血流量, 大脳機能の経年変化に 及ぼす社会的環境因子の影響}

島根医大第三内科

小林 祥泰, 山口 修平, 木谷 光博
岡田 和悟, 村田 昭博, 山下 一也
藤原 茂芳, 下手 公一, 小出 博已
有元佐多雄, 恒松徳五郎

脳血流量は加齢と共に緩徐に減少することが主とし て横断的研究によって知られている。すでに我々は大 脳の老化に社会的環境因子が密接な関与を持つことを 報告したが，今回は同一対象について縦断的検討を行 い, 脳循環の経年変化に及ぼす社会的環境因子の影響 を検討したので報告する。

対象： 2 年半前に脳循環測定を施行した健常老人 75 名の内, 経年変化を追跡しえた老人ホーム在住老人 ( I 群) 20 名（男 9 名, 女11名) (平均76歳) 打よび地域在 住志願老人 (II 群) 40名（男18名，女 22 名）(74歳）の 計60名である.対象者はいずれも日常生活に支障なく， この間に心身共に大きな変化を認めていない。

方法：1）局所脳血流測定法： ${ }^{133} \mathrm{Xe}$ 吸入法により 測定した。2)知能評価：言語性知能は長谷川式簡易知 能スケール，動作性知能は Kohs's Block Design Test で評価した。測定間隔は約 2 年半である。

結果：1）平均血圧は I 群では変化なかったが, II 群 でー7\%と有意に低下した．Ht，総コレステロールは II群で各々 $3 \%, 13 \%$ 上昇した。 2 ） 全脳平均脳血流量
は初回測定時 I 群でII群に比し低值であったが， 2 年 半の期間では両群とも有意の変動を示さなかった。脳 血管抵抗についても同様であった．3)動作性知能は両 群とも有意の変化を示さなかったが, 言語性知能は I 群でー7.5\%, II 群でー $12.9 \%$ といずれも有意の低下を 示した。 4)局所脳血流についてみると両群とも左半球 頭頂部でー $6 \%$ 前後の局所的な減少を示した。

結論：日常生活の活動性が保たれている限り, 高齢 者であっても 2 年半程度の期間では全脳平均血流量は 減少せず，動作性知能はよく保持された。言語性知能 の低下と局所脳血流の減少は関連していた。これらの 経年変化に社会的環境因子の影響は認められなかっ た。

\section{8. アルツハイマー型老年痴呆の脳循環代謝} 日本医大第二内科

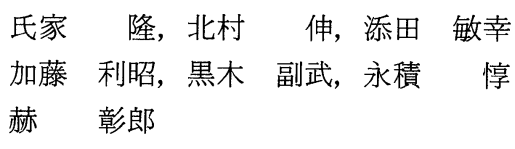

国立中野病院放射線科 初石病院会津 博慈会記念病院内科 飯尾 正明 修，唐崎美千代 伊与田浩介

痴呆の精神機能に対する障害の程度と, 局所脳血流 量 $(\mathrm{rCBF})$, 脳酸素消費率 $\left(\mathrm{rCMRO}_{2}\right)$ との関連を調 べるために，痴呆患者に ${ }^{15} \mathrm{O} を$ 用いたポジトロンCT を実施し，また変性性痴呆と血管性痴呆の形態学的変 化の差異を調べるために一部症例に MRI-CT を実施 した。

対象は老年正常者 5 例(平均年齢65.2歳), アルッハ イマー型老年痴呆 (SDAT) 12例 (72.5歳), 多発梗塞 性痴呆（MID）15例（70.5歳）である。痴呆の重症度 は, 柄沢の臨床的評価基準, 長谷川式簡易知的機能評 価スケール，さらにSDATでは Gottfries-BraneSteen(GBS)スケールにより評価した。PET は ${ }^{15} \mathrm{O}$ 持 続吸入法による steady state techniqueにより， HEADTOME-II を用いてデータ採取した，MRI-CT は常伝導型 G-10（0.15 Tesla，空間分解能 $2 \mathrm{~mm}$ )を用 w, SE 像 (repetition time $1200 \mathrm{msec}$, echo time $60 \mathrm{msec}$ ) に扔いて認められる白質の高信号域病変の程 度を Brant-Zawadzki らの patchy white matter lesions (PWMLs) スコアで分類した. SDAT の初期 に敃いては側頭葉における $\mathrm{CBF}, \mathrm{CMRO}_{2}$ の低下が最 も著しいが, 痴呆が進行すると前頭葉や頭頂葉の低下 も顕著となる。一方, MID では stage I, IIを通じて前 
頭葉に和ける $\mathrm{CBF}, \mathrm{CMRO}_{2}$ の低下が顕著であった。 SDAT の運動機能に関しては前頭葉, 側頭葉, 知的機 能と感情機能に関しては前頭葉, 側頭葉, 頭頂葉の $\mathrm{CBF}, \mathrm{CMRO}_{2}$ の值と有意の相関があった. PWMLs ス コアは, 老年正常者, SDAT が 1 ○すなわち側脳室 周囲に限局しているのに対し, MID では $3 \sim 4$ と側脳 室周囲以外の白質にも高信号域病変を認めた。

SDATの痴呆症状発現には側頭葉の，MIDに打い ては前頭葉の機能低下が関与し，特にMIDに特いて はMRI-SEで認められる白質病変の存在が前頭葉と の連絡線維の途絶をきたす可能性が示唆された。

\section{9. 痴呆患者の薬物点眼試験}

東京医大老年科

羽生 春夫, 桜井 博文, 南條 悦子

山口 克彦, 岩本 俊彦, 勝沼 英宇

東所沢病院

高崎優

西武川越病院

藤田 龍一

アルッハイマー型痴呆患者では, 血清ドーパミンー $\beta$ 水酸化酵素活性の低值や, 心電図 R-R 間隔変動係数の 低值が報告され，交感，副交感神経機能の障害が示唆 される，我々はエピネフリン点眼試験を用い，老年期 痴呆患者の自律神経機能を検討したので報告する。

対象・方法：60歳以上の眼科的異常を認めない老年 者のらち，健常老年者 (N) 25例 (76.9土9.4歳), 痴呆 を認めない慢性期脳血管障害 (CVD) 13例 (73.8 48.2 歳), 脳血管性痴呆 (VD) 19例 (76.2 0 8.1歳), アル

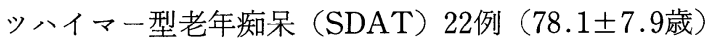
を対象とした. $1.25 \%$ l-epinephrine 点眼 60 分後に肉眼 的に瞳孔径を計測し，散瞳率（\%)（散瞳量/点眼前瞳 孔径 $\times 100$ )を求めた。

結果：(1) $\mathrm{N}$ 群の散瞳率は60歳台20.6土6.6, 70歳台 $26.4 \pm 9.9,80$ 歳台 $27.8 \pm 6.2,90$ 歳台 $39.7 \pm 12.3$ と加 齢に従い大となる傾向がみられた。(2)各群の散瞳率は,

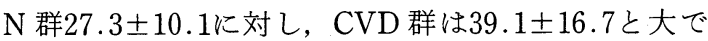
あったが有意ではなかった。これに対し VD群 $44.2 \pm$ 22.6, SDAT 群53.5土18.0 と有意に散瞳率は大となっ た $(\mathrm{p}<0.05, \mathrm{p}<0.001)$. (3)痴呆の程度との関連につ いては, SDAT 群で軽度痴呆 $45.2 \pm 16.3$, 中等度痴呆 $49.6 \pm 6.3$, 高度疾呆 $62.4 \pm 21.2$ と痴呆の進行に伴い大 となる傾向がみられたが，VD群では明らかな関連は みられなかった. (4) SDAT 群, VD 群共に, ADL, 罹 病期間との間に相関はみられなかった。

考察：痴呆患者で有意な散瞳を認めたことは末梢交
感神経機能の障害を示唆する.SDAT では痴呆症状と の関連が深いことから, 中枢神経障害が transsynaptic に 2 次的に末梢自律神経系に影響を及ぼしている可能 性が考觉られる。

痴呆患者に和いて，生命現象の保持と内部環境の調 整に重要な役割を果たしている自律神経系が障害され ていることは，患者の治療，予後を考える上で重要な 意義をもつものと思われる。

\section{0. 痴呆患者の日周リズムの乱れとグルココルチコ} イドの日内変動

日本医大第二内科

$\begin{array}{llll}\text { 海江田 } & \text { 亮, 濱本 } & \text { 真, 今津 } & \text { 修 } \\ \text { 北浜 } & \text { 正, 永積 } & \text { 憞, 赫 } & \text { 彰郎 }\end{array}$

目的：老年期痴呆に拈ける精神症状の一つとして問 題になっている夜間せん妄，昼夜逆転に着目し，その 原因の一つとして体内時計の変調, 内因性日内リズム の変調を確める為, 内因性のリズムを持ち, 加齢の影 響の少ないグルココルチコイドに着目し，その日内変 動について研究を行った。

対象：当科及び関連病院入院中の老年期痴呆患者, アルッハイマー病患者を対象とした。疾呆の診断には, DSM-III を用い，天科法，ischemic-score，CT, 臨床 症状等により，MID，SDAT，MIX 等に分類診断を 行った.アルッハイマー病の群を除いて他の痴呆群に 扣いて年齢，性別共に有意差を認めなかった。 又，こ れらの老年期痴呆患者に対し，年齢，性をマッチさせ た正常老人を対照とし検討を加えた。（重篤な疾患を持 たず，知的能力の正常なものをいわゆる正常老人とし た.)

方法：対象に対しその行動記録を睡眠一覚醒一問題 行動の三点に着目し，その日計表を作成した。この観 察期間中の一日に抽て，5時と17時に安静臥床の後 採血を行い，血中 ACTH，グルココルチコイドの測定 を行った。同時に一部の症例に 5 時から17時, 17時か ら 5 時までの 12 時間蓄尿を行い尿中 $17 \mathrm{OHCS}$ の変動 を観察した。

結果：正常老人と老年期痴呆患者との対比では $\mathrm{ACTH}$ は痴呆患者に执いて低值であり,その日内リズ ムは消失している例が多かった。 又，同様の事がアル ツハイマー病患者に拈いても認められた。血中コーチ ゾールはACTHに対し，リズムは保たれている例が 多かった. MID と SDATとの比較において, SDAT にリズムの消失が強くみられた。 


\section{1．剖検よりみた日本人前立腺の観察}

慈恵医大泌尿器科

田代 和也, 和田 鉄郎, 吉越富久夫 大石 幸彦, 町田 豊平

同 病理. 古里 征国, 松本 出

日本人の正常前立腺の経年的変化を知る目的で術前 に泌尿器科的疾患の既往のない剖検例 300 例を対象と して, 摘出前立腺の重量, 大きさの検討を行った。 方 法は前立腺を剖検時に全摘し，ホルマリン固定後に重 量，大きさの計測を行った。前立腺重量は40歳代をで 経年的に徐々に増大し平均 $25.6 \mathrm{~g}$ までなったが，その 後一時減少し，60歳代より再度増大する傾向がみられ た。これを結節形成をみる結節型と作らない非結節型 に別けると, 結節型は 40 歳以降も徐々に増大し，60歳 代以後に急速に増大し 80 歳代では平均 $47.5 \mathrm{~g}$ までに なっていた。これに対し非結節型は40歳以降も汪とん ぞ変化がなかった。摘出前立腺の大きさは40歳代まで 加齢とともに上下径 $29.7 \mathrm{~mm}$, 左右径 $40.6 \mathrm{~mm}$, 前後径 $34.8 \mathrm{~mm}$ とともに延長するが，40歳代以後は結節型の みで増大したが，非結節型では重量と同様に注とんど 変化しなかった，尿道長は40歳代以降汪とんど変化が なかった。しかし，尿道を精丘より膀脱までと精丘か ら括約筋までに別けて計測すると，結節型では精丘よ り膀胱までの長さの延長がみられた。 以上，最近の日 本人の前立腺の形態は過去の報告に比べ大きくなる傾 向がみられ，欧米のそれと同様になっていることがわ かった.

\section{2. 高齢者における子宮留膿腫の検討}

都多摩老人医療センター婦人科赤澤 憲治 都老人医療センタ一婦人科桶口龍夫

同感染症科稲松 孝思

最近 2 年間に東京都老人医療センターで扱った子宮 留膿腫11例の臨床検討を行なった。平均年齢は81.1歳 であった。

11 例中 10 例は婦人科で治療を行なった。これらは婦 人科外来初診者の $4.5 \%$ に相当した. 残り 1 例は他科で 診療を行なった。をた，この10例中 5 例は婦人科に入 院し治療を受けた。これは婦人科入院患者の $6.3 \%$ に相 当した。残り 5 例は他科に入院中の症例で，婦人科医 の往診による治療を行なった。11例中 2 例に子宮頝癌 の合併を認め, 残り 9 例は婦人科合併症を認めなかっ たが,このうち 7 例が寝たきり又は殆んど寝たきりで，
2 例が車椅子移動又は介助歩行であった，婦人科合併 症を認めなかった 9 例中 7 例に尿，便失禁を認めた。 子宮内に貯留した膿の細菌学的検査を行なった 9 例中 8 例に病原性を有する嫌気性菌が単独又は好気性菌と の混合感染として認められた。宮留膿腫に起因する と思われる全身感染症状, 所見を呈したのは11例中 7 例であった，治療としては，抗生物質の全身投与より も経子宮䅡管的ドレナージ及び子宮腔内洗浄が有効で あった。11例中10例は軽快したが，1例は敗血症性 ショックで死亡した。この例は, 剖検にて敗血症の原 因病巣としての子宮留膿腫の存在が判明した。

子宮留膿腫は婦人科疾患の約 $1 \%$ 占め, 更年期以 降の婦人で, 子宫頝癌, 体癌の合併例, 及びこれらに 対する放射線治療後に発症しやすいといわれている. しかし, 老人病院での本症発症頻度はかなり高く, こ れら婦人科合併症がなくとも生理的な帯下の流出が不 良で, 尿, 便の腔内混入が生じやすい寝たきり老人等 では発症しやすいことが示唆された。 今後, 老年層の 増加，とりわけ寝たきり老人の増加に伴ない，本症の 発症率が増加することが予想される。

\section{3. 高齢者の癌患者長期生存例に対する免疫能と心 身医学的考察について}

相模原南病院

\section{中川 俊二}

癌の自然退縮拈よび進行癌の長期生存例 ( 5 年以上) は極めて少ない症例であるが，組織学的所見による基 準をもとに，われわれがいままで12年間のうちに収集 したケースは各施設の協力で65例に達した。 そのらち 60 歳以上 65 歳まで14例， 66 歳以上 9 例で高齢者が 23 例 (33\%) であった。臓器別では消化器癌 (48\%), 呼吸 器癌 (33\%) が多く, 子宮, 上顎癌, 副腎腫などで, 組織別では腺癌, 扁平上皮癌が多くみられた。実施さ れた不完全な治療法としては非観血的療法, 姑息療法, 無処置のものもあり, 免疫学的調査打よび心身医学的 面の調査も行い，高齢者特有の興味ある成績が学られ た。

\section{4. 老化は末梢リンパ球严分画を変動させるか}

東大物療内科後藤畺, 宮本 昭正

日本免疫研究所 小玉健次郎，久下栄

末梢リンパ球分画の詳細な解析は, 個々人の免疫状 態を知るうえでの貴重なデータベースとなるものであ ろら. 特に最近, モノクローナル抗体が加速度的に生 産され，そのモノクローナル抗体を組み合わせること 
により,より精度の高い, リンパ球亜分画の同定が可 能となってきた.これは, 二次元フローサイトメーター の進歩の力も大きく与っている．信頼できるテクニッ クによれば, 二つのモノクローナル抗体の組み合わせ により, Leu $2 \mathrm{a}^{+} 15^{+}$は, サプレッサーT 細胞, Leu $2 \mathrm{a}^{+}$ 15ーはキラーT 細胞, Leu3a+8+はインデューサーT 細 胞, Leu3a8-はヘルパーT 細胞であり, Leu4 ${ }^{+}$HLA $\mathrm{DR}^{+}$は活性化 $\mathrm{T}$ 細胞と分類され, 機能との相関も確認 されている.

我々は，健常人に和ける加齢，性の影響をみるため， 20 歳から100歳までの健常人男女156名ならびに早期老 化症候群ウエルナー症候群患者11名を FACS IVを用 いて検索した. 老化に伴って $\mathrm{T}$ 細胞の低下が存在する ことは，広く知られた事実であるが，我々の検索でも， 特に女性で, Pan T 細胞 (Leu1+あるいは, Leu4 ${ }^{+}$) の 年踚に従って低下していく傾向が認められ，多くのウ エルナー症候群患者でも同様の傾向が認められた。 た，一般的には加齢に従って，個体差が大きくなるよ らであった。これらの T細胞系の低下をひさ抗こす主 なリンパ球亜分画は, 执そらくLeu2 $\mathrm{a}^{+} 15^{-}$, Leu7-11+ のキラーT 細胞, ナチュラルキラー細胞と考学られ た.こらしたリンパ球亜群の割合の低下は，一般的に 知られている加齢に伴う活性の低下と対応すると思わ れるが，リンパ球数と活性との比較は今後, 更に検討 を加える必要があろう。

\section{5. 動脈硬化症および高血圧症の有無と補体系との}

\section{関係}

島根医大第三内科, 島根難病研究所

\section{山内 康平, 恒松徳五郎}

目的：従来, 動脈硬化の要因として高血圧, 高脂血 症, 血小板凝集京進, 契煙やストレスが研究の中心で あった.しかし, 私共は動脈硬化症を補体免疫炎症学 的見地から把握し，第21回本学会でも述べたように日 常の風邪症候群から始まって繰り返す炎症反応がその 原因となると考兵る。毎年何度か反復する炎症やそれ に続く免疫アレルギー反応が血管壁の障害や硬化を進 展させるが，その傍証を得るために，加齢に伴う炎症 の一指標である補体や免疫グロブリンの変動拉よび各 年代別に高血圧群と正常血圧群で比較した。

方法：住民健診にて20歳代，30歳，40歳，50歳，60 歳, 70歳代以上と高血圧群および正常血圧群を統計的 有意数の 30 名以上づつを選び総コレステロール（T. C.), 中性脂肪 ( TG), IgG, IgA, IgM, 補体溶血活性
$\mathrm{CH}_{50}, \mathrm{C}_{3}, \mathrm{C}_{4}, \mathrm{~B}$ 因子を通常の方法で測定し, $\mathrm{t}$ 検定 にて有意差を検討した。

結果：先ず予備的に行った $\mathrm{CH}_{50}$ は各年代順に 31.0 $\rightarrow 32.4 \rightarrow 36.4 \rightarrow 38.1 \rightarrow 38.3 \rightarrow 41.0 \mathrm{U} / \mathrm{m} l$ と加齢と共に 上昇した。 これは加齢と共に炎症状態が高まる傾向を 示唆している. 次に最大血圧 140 , 最小血症 $90 \mathrm{mmHg}$ 以 上群と正常群を比較した結果， $\mathrm{C}_{3}, \mathrm{C}_{4}, \mathrm{~B}$ 因子に拉い て30歳代，40歳代，60歳代で高血圧群が有意 $(p<0.01)$ に高值を示した。 50 歳代と70歳代以上では両群に有意 差は得られなかった。

TC は高血圧群で常に高值であったが, 有意差を示 したのは30歳代と40歳代であった，TGでも高血圧群 は常に高值であり，30歳，40歳，60歳代では有意 $(p<$ 0.01)に高值であった. IgG では60歳代において高血圧 群 $1,546 \pm 326$ に対し正常血生群 $1,301 \pm 289$ と有意差を 示した， IgA は常に高血圧群が高值であったが，有意 差は認めなかった. IgM は50歳代にのみ有意差を認め た. 以上の成績は加齢と共に何らかの慢性炎症状態が 存在し, 高血圧や動脈硬化を形成していると解釈でき る結果であった。

\section{6. 脂質と補体（第 1 報）}

日大第二内科

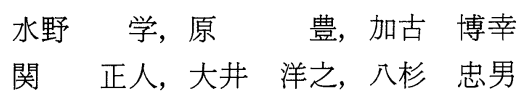

目的：動脈硬化の病態については多くの未解決の問 題がある.今回そのひとつである non-specific に反応 し種々の生物学的活性をもたらす補体系に注目し, 今 回は各種 Cholesterol によりいかに補体が活性化され るかを検討した。

方法：脂質としては Cholesterol oleate(C.O), Cholesterol palmitate (C.P.), Cholesterol linoleate (C. L.), Free cholesterol (F.C.), 以上はシグマ製および $25 \mathrm{ml}$ の hot ethanol に溶解し加熱後冷水を加光濾過 乾燥して得た Crystalline cholesterol (C.C)を用いた. 各 material は以下の 4 つの条件のもとに $1 \mathrm{ml}$ の Normal human serum (N.H.S.) と反応後 2 次元電気泳動 を行ないC3 conversionを観察した。 4 つの条件は （1） NHS + sample を承中にて混和，(2) NHS+sample in $0.01 \mathrm{M}$ EDTAを $37^{\circ} \mathrm{C} 30$ 分反応（3） NHS+ sampleを $37^{\circ} \mathrm{C} 30$ 分反応（4） NHS+ sample in $\mathrm{EGTA}+\mathrm{mg}^{2+を} 37^{\circ} \mathrm{C} 30$ 分反応させた. Buffer 及び agarose 中には0.01M EDTA を加えた. C3の conversion は native C3 と C 3c の面積を算出し全体の面積に 
対する C 3c の面積の割り合いを\%で表した。

結果：(1) C.O., C.P., C.L., は2mg では C3 conversion を認めず $50 \mathrm{mg}$ にても僅かに C3 conversionを認 めるにすぎなかった。 (2) F.C.は2mg で明らかな C3の conversionを認めた。 この活性化は Alternative pathwayによるものであった. (3) C.C.は F.C.に比較しさ らに Alternative pathway を活性化した. 以上の結果 より動脈硬化を考える上で動脈壁や，その構成細胞の 障害因子として，補体活性は無視できない要素である と思われる。

\section{7. ヒト腎臓の加齢変化一腎内動脈計測值と腎組織 計測值との相関一}

\section{神戸常盤短大衛生技術科}

後藤 正徳, 川純一, 宮崎 吉平

ヒト腎臓の加齢変化について，我々は，過去 4 回， 本学会総会に於て組織計測により定量形態学的に研究 した成績を報告して来た。これらの成績では，腎臓を 4 部位，被膜直下域皮質，皮質中央，皮質直下域髄質 及び腎賈辺縁髄質に分けて加齢変化を検索したが，加 齢変化と相関する主たるものは，(1)腎重量の減少，(2) 硝子化糸球体系の増加であり，加齢変化の主たるもの は，ネフロン数の減少であろうと推定された。同時に 分析された腎内の微量重金属 $(\mathrm{Cd}, \mathrm{Cu}, \mathrm{Zn}, \mathrm{Fe})$ 濃度 には加龄変化はみとめ得なかった。今回は腎内動脈血 管の組織計測を実施して，その加齢変化を検索すると 共に，腎組織計測値との相関をみてみた。

研究材料及び方法：臨床的にも病理学的にも著変が ないと推定される腎臓で，これまでに組織計測を実施 し本学会に報告して来たもののうち，42例の腎臓につ いて腎内血管の計測を実施した。すなわち，弾力線維 染色を施した顕微鏡標本を用い，動脈血管について， その大きさとは無関係に，(1)内腔面積，(2)内弾性板で 囲まれる面積，(3)外弾性板で囲まれる面積，を顕微鏡 下で測定した。これらの血管は大きさが異るので，計 測值から，〔 $\mathrm{A}=($ 内弾性板で囲まれた面積) - (内腔面 積) /(外弾性板で囲まれた面積) ], 〔B=(内腔内積) / (内弾性板で囲まれた面積) $]$, 及び $[\mathrm{C}=$ (内腔面積) / (外弾性板で囲まれた面積)]を計算し，これら $\mathrm{A}, \mathrm{B}$, Cの値についての加齢変化を検討した。

研究成績 : 腎内血管の計測比 $\mathrm{A}$ は, 加齢と共に明ら かに低下し $(\mathrm{R}=-0.753)$ ， B は明らかに増加（ $\mathrm{R}=$ 0.753)する. 又，Cはやや加齢と共に低下する。すな わち，腎内の動脈血管は，加齢と共に内膜が肥厚し，
内腔の狭小化と血管壁筋性肥厚が強くなる傾向を示 す.この所見と腎組織計測值との相関をみてみると， 腎皮質の糸球体硝子化は, 明らかに腎内血管の計測比 A， B の加齢変化と相関している.

\section{8. 腎機能障害高齢者における電解質および酸塩基 平衡異常について}

都老人医療センタ一内分泌科

藤巻 博, 中野 忠澄
白木 正孝, 井藤 英喜

緒言：腎機能障害に伴う電解質および酸塩基平衡異 常についての研究は, 従来, 一般成人を主な対象とし て行われており，高齢者については充分な検討がなさ れていない。ここでは65歳以上の高齢者を対象とし， creatinine clearance（Ccr）と血清電解質および血液 ガス分析值との関係から，高齢者の特殊性について検 討を行ったので報告する。

対象および方法：Ccr $40 \mathrm{~m} l / \mathrm{min}$ 以下の腎機能障害 高齢者 45 人（男性 24 人，女性 21 人，平均年齢 79.0 歳） を対象とした。腎機能障害の基礎疾患は, 腎硬化症, 糖尿病性腎症，慢性腎炎などが主要疾患であった。な 扣，腎機能障害以外の原因で著明な電解質酸塩基平衡 異常を発現する疾患患者は除外し, また, 利尿剂, ア ルカリ化剂，ステロイド剂，非ステロイド系消炎剂， phosphate binderなどを使用している症例も除外し た. 例外として, 40〜 120mg/day 程度の furosemideを 使用している末期腎不全患者は対象に含めた。血液生 化学的検查, 血液ガス分析, および C cr 測定は原則と して同日に施行した。

結果拈よび考案：従来の報告と同様，Ccr 低下に伴 い, hyponatremia, hyperkalemia, hypocalcemia $の$ 発現を認めた。一方，今回の検討での特異な所見とし ては, Ccr 低下に伴う hyperchloremia と normal anion gap acidosis の発現であった. anion gap が増 加しない成因としては，腎不全における anion gap 増 加の主要な要因である hyperphosphatemia が比較的 軽度であったことと, 血清アルブミン值が低值であっ たことが考えられた。高齢者におけるこの特異性は hyponutritionを反映しているものと推察されたが, 今後の課題として, renal tubular acidosis, type IV の 関与について検討する必要があることが示唆された。

339. 糖尿病性腎症による慢性腎不全の透析療法にお ける予後の検討 
社保中央総合病院内科透析科

$\begin{array}{crrrr}\text { 澤田 } & \text { 皓史, 近藤 } & \text { 剛志, 佐賀 } & \text { 宗彦 } \\ \text { 谷 } & \text { 雅秀, } & \text { 梶原 } & \text { 慶三, 瀬田 } \text { 克孝 } \\ \text { 東大老年病 } & \text { 鳥羽 } & \text { 研二, 松瀬 } & \text { 健 }\end{array}$

目的：昨年末の時点で日本全国の透析患者数は 6 万 人にまで増加したが，近年透析導入される患者の中で 老年者あるいは糖尿病者が占める割合が大きい.しか もこれらの患者達の予後は一般に不良とされて和り， その改善のためには予後への影響因子の探求が必要で ある。

方法：当院の透析施設が昭和 47 年 9 月に開設されて 以来の，糖尿病性腎症による腎不全のため透析療法実 施患者について，生存率・死亡時期・死因等について 調査した。

結果：昭和 52 年 2 月に糖尿病性腎不全の第一例を透 析導入して以来計 50 名の累積があり, このらち27名が 死亡していた。導入後の生存期間は 6 力月未満, 6 力 月〜 1 年末満, 1 年 3 年末満, 3 年以上と 4 群に区 分してみると，それぞれ $7,7,9,4$ 人と分布し，導入 期（第 1 回透析後 6 力月未満とすると）の死因として, 自殺，シャントトラブルが目立った。老年者では特に 導入期にトラブルが多く，入院期間が延長する傾向が あった. 1 年生存率は72\%で全国平均にほぼ近似した。 老若間に大きな 1 年生存率の差はなかった。自律神経 障害（起立性低血圧，胃腸症状）は 1 年生存率へ有意 の影響を示した。長期透析患者の死因としては，高力 リウム血症を含さ心不全, 脳血管障害, 消化管出血が 多かった。著明な小細動脈硬化に大動脈硬化の伴わな い症例も認められた。

結論：透析導入期の死亡が多くないことは，導入期 の代謝変化が患者への過大な負荷になっていないこと を示唆する。糖尿病透析患者の予後を改善するために は，適正な透析療法のためのたゆま細心の注意と努 力が必要でありかつ透析以前の早期から動脈硬化の予 防対策も不可欠である.

\section{0. 高齢者経皮的腎尿管結石摘出術の問題点}

日本医大泌尿器科

坪井 成美，西村 泰司，秋元 成太

目的：1982年 5 月以来, 日本医科大学附属病院およ び関連病院に拈いて施行した経皮的腎尿管結石摘出術 は最年少 6 歳から最高齢81歳までで170例を越えてい る.そのらち60歳以上の症例は男性 9 名, 女性 5 名, 計14名であった。60歳未満の患者群と比較し，高齢者
に特有の問題点の有無を検討した。

方法：経皮的腎尿管結石摘出術は，硬膜外麻酔また は腰椎麻酔を施行し，X 線透視下または超音波ガイド 下に腎穿刺を行ない，ガイドワイヤーを腎盎に留置す る.筋膜ダイレーターを用い $22 \sim 36 \mathrm{Fr}$ までの腎瘦を造 設する，腎血鏡，胆道鏡などの内視鏡を腎血，尿管に 挿入し，種々の結石破砕器と結石鉗子を用いて結石を 腎瘻を通して体外に摘出する手技である。本法に扣け る高龄者の入院期間, 発熱, 出血などの合併症の有無 につき比較検討を行なった。

結果：14例中 1 例では結石摘出不能で, 開腹手術と なった。 1 例では, 術前より心房細動を認めていたが, 術後心筋硬塞によると思われる心不全にて死亡した。 経皮的腎尿管結石摘出術成功例 12 例に拈いては，入院 期間，発熱，出血などにおいて，60歳未満の群との間 に有意差は認められなかった，高血圧症，心疾患，糖 尿病などに関しても差は認められなかった。

結論：手術侵襲に対する高齢者の予備力は低下して いると考えられ，術中，術後の厳重な管理が必要であ る. 麻酔が可能な状態の患者であれば，尿路結石に対 する手術法としての経皮的腎尿管結石摘出術は，高齢 者に対しても安全な手技であると考える。

\section{1. 腎の加歯令と利尿期のリン排泄}

都多摩老人医療センター内科 井上 剛輔 東大老年病鳥羽 研二, 折茂 肇

目的：腎の加齢現象の中で, 電解質異常としてはナ トリウム $(\mathrm{Na})$ 保持機能の低下が指摘されているが, 他の電解質の態度については明らかにされていない。 われわれはさきの本学会において，尿中 $\mathrm{Na}$ 排泄分画 (FENa)が年齢および血圧によって影響され，両因子と も利尿的に排泄促進的に作用することを報告した. $\mathrm{Na}$ の腎からの排泄は，近位および遠位で行われるので， 利尿期の変化は主として遠位部での加齢変化と判断さ れたが，近位部での変化も直接には除外できない.リ ン (P) は電解質の中で近位尿細管機能の指標とされて いるので, 今回は, $\mathrm{Na}$ と $\mathrm{P}$ の利尿期と濃縮期の排泄態 度を比較し, 尿細管の加齢変化の部位を推測してみた。

方法：東大老人科入院患者で，心，腎，肝疾患およ び糖疛病患者を除外した 20 名に, 早朝, 水負荷 $(15 \mathrm{~m} l)$ $\mathrm{kg}$ 体重) 試験とバゾプレッシン負荷 ( $4 \mathrm{mU} /$ 分点滴) 試験を実施し，最大稀釈時（利尿期）および濃縮時の 尿につき， $\mathrm{Na}$ と $\mathrm{P}$ を測定し, 排泄量を求めてから，P の稀釈/濃縮比と $\mathrm{Na}$ のそれとを比較し, 加齢扣よび血 
圧の影響を観察した。正常血圧群と高血圧群とは平均 血圧 $110 \mathrm{mmHg}$ 前後で区別した。

結果：1. $\mathrm{Na}$ の稀釈/濃縮比は，年齢および血圧の 影響から，1 以上が多かったが P では，とくに高血圧 群で 1 以下の場合もあり, 圧 $\mathrm{P}$ 利尿 (Pressure Puresis）の存在が推測された。2. 年齢と $\mathrm{P}$ の稀釈/濃縮 比に相関はみられなかった。 3 . 稀釈/濃縮比の $\mathrm{Na} / \mathrm{P}$ 比を求めると, $\mathrm{Y}$ (尿中 $\mathrm{Na} / \mathrm{P}$ 比) $=9.4-0.12 \mathrm{X}$ (年齢) $(\mathrm{p}<0.05)$ (正常血圧群), $\mathrm{Y}=2.7-0.026 \mathrm{X}(\mathrm{p}<0.05)$ (高血圧群) であり, 両直線の差は有意であった。

考案と結論：P排泄に血圧の影響が強いこと，㧤よ び, $\mathrm{Na} / \mathrm{P}$ 比からは70歳以上では $\mathrm{Na}$ と $\mathrm{P}$ の排泄比が 1 に近ずき, 遠位部の障害による近位部の排泄態度が 推測できる所見であった。 また高血圧群ではより若年 者でも $\mathrm{Na} / \mathrm{P}$ 比が老年者に近似し, 加齢の促進現象と 解釈された。

\section{2. 系球体過剰沪過モデルにおける腎髄質機能の研} 究 (第 1 報)

東大老年病 鳥羽 研二, 折茂 肇
都多摩老人医療センター

蛋白過剰摂取や高血糖が腎糸球体の過剰灌流，ひい ては過剰沪過をひき掞こすことが，ブレナーらにより 報告されている。これは腎の老化とも密接な関連があ ると考觉られる。我々は急性のアミノ酸負荷により作 製した過剩汇過ラットにおいて腎機能を検討し若干の 知見を得たので報告する。

方法：ウィスターラット（210～330g，オス）を 24 時 間絶食させた後,ネンブタール麻酔をし，経尿管的に 腎孟に採尿カテーテルを打いた。リンゲル液点滴によ るコントロールクリアランスを施行した後に, $3 \%$ ア ミノ酸を, $3 \mathrm{~m} l / 100 \mathrm{gBW} / \mathrm{hr}$ の速度で点滴し, クラアラ ンスを行い, 前後で Ccr, FENa, $\mathrm{FECl}$, 腎孟尿 $\mathrm{PO}_{2}$, 動脈血 $\mathrm{PaO}_{2}$ を測定した。

結果：負荷前後の C cr は 16.2 から $31.4(\mathrm{ml} / \mathrm{hr})$ と有 意に増加した $(\mathrm{p}<0.05)$.この時腎孟尿 $\mathrm{Po}_{2}$ は81.7から 43.8 (Torr) に有意の低下が観察された。一方動脈血 $\mathrm{PaO}_{2}$ は前 100.1 後 100.4 と不変であった. FENaは負荷 前 $24.0 \%$, 負荷後 $10.4 \%$ と有意に $(\mathrm{p}<0.05)$ 低下, $\mathrm{FECl}$ も，負荷前後で 31.6 か 13.1 と有意に低下した $(\mathrm{p}<$ 0.05).

考察：腎孟尿 $\mathrm{PO}_{2}$ は腎髄 $\mathrm{PO}_{2}$ と平衡することが知ら れている。アミノ酸負荷により腎孟尿 $\mathrm{PO}_{2}$ が低下した ことは, 過剰沪過時に腎䯣質の低酸素血症が引き扣こ
されたと考光られる.同時に $\mathrm{FENa}$ と $\mathrm{FECl}$ の低下が観 察されたことは，これらのイオンの髄質に扣ける active transportにより $\mathrm{O}_{2}$ が消費された可能性を示 唆するが，これらの再吸収増大の機序は今後更に検討 を要すると思われる。

腎髄質の低酸素や虚血は, 腎髄質の機能低下や, 器 質的変化をむたらすことが知られている，今回のアミ ノ酸負荷による腎髄質の低酸素状態の知見は, 蛋白の 過䛢摂取が，皮質にとどまらず腎䯣質の機能低下や， 加齢変化の促進に影響する可能性を示唆するものと考 えられる。

\section{3. ${ }^{99 m}$ Tc-DMSA SPECT 腎イメージょり求めた} 老年者腎機能一 ${ }^{99 m}$ Tc-DMSA 腎摂取率による検討一 慈恵医大泌尿器科

$$
\begin{aligned}
& \text { 大石 幸彦, 町田 豊平, 田代 和也, } \\
& \text { 和田 鉄郎, 吉越富久夫 }
\end{aligned}
$$$$
\text { 都老人医療センター核放山田 英夫 }
$$

目的: Single photon emission computed tomography（SPECT）で得た腎横断断層イメージより腎摂取 率を算出する分腎機能測定法を試み, 老年者の腎機能 を測定した。

対象：対象は $20 \sim 45$ 歳, 平均 30 歳の成人健常対照例 20 例, $60 \sim 87$ 歳, 平均 70 歳の老年者 30 例(正常例 10 例, 腎摘後単腎 5 例，腎機能障害 4 例，“高血圧，腎腫瘍掠 のおの 3 例, 腎囊腫, 腎梗塞沶の扮の 2 例, 腎炎 1 例) の計50例である。 $\gamma$-カメラは GE-Maxi camera 400T 回転型を使用し, ${ }^{99 \mathrm{~m}} \mathrm{Tc}$-DMSA $10 \mathrm{mCi}$ 静注 2 時間後, 64方向より腎投影データを採取, 重畳積分法でマト リックス $64 \times 64$, 厚さ約 $0.6 \mathrm{~cm}$ の断層画像を再構成し た. 各断面の面積の計数を算出, 厚みを掛け, 腎容積, 腎内総計数を算出した。吸収補正は GE-STAR 法, cut off level は42\%を使用した。腎摂取率は放射能既知の ファントム実験より求めた放射能曲線と容積内総計数 counts $/ \mathrm{m} l / \mathrm{sec}$ から, 腎内総計数を $\mathrm{mCi}$ に換算, 投与 量に対する百分率で表した。腎容積と腎摂取率の相関, 総腎摂取率と Ccr 值との相関をみた。

結果: 成人正常対照例 20 例 40 腎の腎容積々腎摂取率 はおのおの $225 \pm 28 \mathrm{~m} l, 27 \pm 2 \%$ お゙った. 老年者 10 例 20 腎の腎容積と腎摂取率はおのおの $212 \pm 44 \mathrm{~m} l, 23 \pm$ $5 \%$ ，腎摂取率は成人対照例に比較し有意に低值を 示した。老年者30例56腎の腎容積と腎摂取率 $(r=$ 0.605)，28例の腎摂取率と Ccr 值 $(r=0.591)$ とは比 較的良好な相関を示した。 
結論：SPECTで得られた ${ }^{99 \mathrm{~m}} \mathrm{Tc}-\mathrm{DMSA}$ 腎イメー ジから求めた腎容積を基に, 腎摂取率を算出する腎機 能測定法は, 非観血的で, 採血, 採尿を必要とせず老 年者の分腎機能検査法として有用である。

\section{4. アルツハイマー型老年痴呆における反応性イン} スリン過剩分泌と膵島細胞膜抗体

$$
\begin{array}{ccc}
\text { きのこェスポアール病院 } & & \\
\text { 佐々木 健, 石井 園畧 } \\
\text { 岡山大神経精神科 } & \text { 藤沢 嘉勝 }
\end{array}
$$

目的：我々はアルッハイマー型老年痴呆 (SDAT) の病因に糖代謝の異常が関与する可能性を追求してい る. SDAT 患者の多くは, その経過の中で過食傾向(特 に甘(物）末期の極だったるい瘦傾向を認めることな どにより我々はSDAT の糖代謝に注目した。この為 SDAT 群108例と対照老人群57例に75g OGTTを行 い, 更に膵島細胞膜抗体 (ICSA) の検索をSDAT 群 78例, 対照老人群37例に行い, SDAT の原因にインス リン分泌異常を基とする糖代謝の異常が関与している 可能性を探った。

方法：きのこエスポアール病院に入院中, 外来通院 中の SDAT 群108例と非痴呆老人群57例につき比較検 討した. SDAT は DSMIII Criteria とCT 所見を基に 診断した. $75 \mathrm{~g}$ OGTT は負荷前, 後 30 分, 60 分, 120 分 に血糖, 血清インスリン測定を行い両者の統計解析は Wilcoxon 検定を用いた。 次いでSDAT 群より無作為 に78例, 対照群より37例を抽出し ICSA 検索を行った。 検索は Lernmark らの方法に準じ間接螢光抗体法で 行い丸山らの方法に従って陽性, 陰性の判定を行った。

結果: SDAT群の負荷後30分, 60分, 120 分及び $\Delta \mathrm{IRI}$ のインスリン值は対照群に比して有意に高かっ た. SDAT 群の空腹時血糖值, インスリン値は対照群 と有意の差なく, 各測定時間の何れに打いてもインス リンの反応性過剩分泌を認めた。 糖負荷後 30 分の Insulinogenic index $\left(\frac{\Delta \mathrm{IRI} 30}{\Delta \mathrm{BS} 30}\right)$ に拈いてもSDAT 群 は対照群に比して有意に高かった。血糖は 120 分, $\Delta \mathrm{BS}$ はSDAT 群に有意に低い結果を認めたのみであった。 一方 SDAT 群の ICSA 陽性率は対照群の $8.1 \%$ に比較 して $35.9 \%$ とはるかに高率であった。以上の結果より， SDAT に扣けるICSA の高出現 $\rightarrow$ 膵島 $\beta$ 細胞の機能 異常 $\rightarrow$ 慢性的なインスリン異常分泌反応 $\rightarrow$ 脳糖代謝異 常 $\rightarrow$ SDAT の出現という仮説の基, SDAT の成因に インスリンの分泌異常を基とする脳糖代謝異常が関与
する可能性につき考察したい，加えて糖代謝という脳 代謝にとって最も基本的, 重要なものの研究がSDAT の病因研究の進歩に役立つことを強調したい.

\section{5. アルツハイマー型老年痴呆（SDAT)における各 種神経ペプチドの臨床的意義一第 1 報一}

聖マリアンナ医大神経精神科

高木 博敬, 青葉 安里, 山口 登

常泉 智弘, 千嶋 達夫, 廿楽 通徳

酒井隆, 根岸協一郎, 長谷川和夫

聖マリアンナ医大麻酔科

高橋 敬蔵, 志村 敏雄

目的：近年, 脳内ペプチドの存在が明らかにされて 以来，その㗢きについての数々の報告が発表されてい る。特に脳の高次機能とぺプチドの関係についての報 告の中で精神医学の分野に执ける診断拉よび治療に関 しての報告が認められる様になったが未だ一定の見解 を得ていない，そこで本研究では，髄液掞よび血清に 存在する神経ペプチドの測定值がもつ臨床的意義につ いてアルッハイマー病 (AD), アルッハイマー型老年 痴呆（SDAT）と若年及び老年コントロール群につい て比較検討した。

対象：神経ペプチドは,これまでの SDATに関する 報告の中で陽性所見が得られ，かつ脳の高次機能との 関連が示唆されているペプタイドで髄液中では $\beta$-エ ンドルフィン，血中ではプロラクチン，ソマトスタチ ン， $\beta$ エンドルフィンについて測定した。測定法は RIA 法を用いた。

若年コントロール群は10例で男性 6 例女性 4 例, 年 齢は21歳から51歳までで平均 $33.3 \pm 11.0$ 歳, 老年コン トロール群は, 7 例で男性 3 例女性 4 例, 年齢は67歳 から 80 歳までで平均 $72.4 \pm 4.2$ 歳, $\mathrm{AD} / \mathrm{SDAT}$ 群は10 例で男性 3 例女性 7 例，年齢は 58 歳から 82 歳までで平 均 $68.2 \pm 8.2$ 歳であった。

結果：1）血清中 $\beta$-エンドルフィンは 3 群間に差を 認めず，一方髄液中 $\beta$-エンドルフィンは $\mathrm{AD} / \mathrm{SDAT}$ 群に扮いて高龄対象群より有意の低下を見た。2)血清 中ソマトスタチンは加齢とともに上昇し, $\mathrm{AD} / \mathrm{SDAT}$ 群に打いて若年対象群より有意の上昇を見た。3)血清 中プロラクチンは加齢とともに低下し, $\mathrm{AD} / \mathrm{SDAT}$ 群 に打いて若年及び高齢対象群より有意の低下を見た。

\section{6. アルコールと痴呆に関する臨床的研究}

$$
\text { 名大老年科山本 孝之, 遠藤 英俊 }
$$


河野 和彦, 葛谷 文男

最近，アルコール消費量は非常に増えて抢り，常習 飲酒による痴呆の増加が予想されるが，これに関する 報告は多くない。

我々は，その病態や，背景を明らかにする目的で， 脳血管性痴呆 $(\mathrm{VD})$, アルッハイマー型老年痴呆 （SDAT）を対象として，常習领酒の既往がある患者の 臨床像, 並びに血液諸検查値などについて比較検討し た。

対象は，当科関連病院で, DSM.III の診断基準によ り VD, SDAT と診断された痴呆患者であり, 常習飲 酒とは，日本酒に換算してほぼ 3 合以上を毎日かかさ ず長期にわたって摄取したものとした。尚，毎日飲ん だ酒の量に飲酒年数を乗じたものを飲酒指数とした。 調査項目としては, 痴呆の症状経過, 鿄煙歴, 血液生 化学調査, 免疫機能検査, HLA, 頭部 CT \& EEG ス キャナーなどである。

常習飲酒歴のある痴呆患者の初発症状では暴力, 妄 想，幻覚などが多かった。常習领酒者は，飲酒歴のな い者と比し, どちらも改善率が低く死亡率が高かった。 これはVDで特に顕著であった，飲酒指数 150 以上の 者は, 双方とも予後が悪く改善は認められなかった。

血液生化学検査では, 痴呆の悪化とともにコリンエ ステラーゼが低下する傾向を示し, 免疫学的検査では, 常習领酒者に免疫能の低下を認めた。これらもVDに おいて著明であった。CT 所見では, SDAT は飲酒に よって影響を受けず，VDは飲酒により第三脳室と側 脳室の拡大が見られた。脳波では, VDに扔いてCTの 病変部位に異常脳波が現われた。 HLA では, $\mathrm{A}_{24(9)}$ $\mathrm{Bw}_{22}-\mathrm{Cw}_{1}, \mathrm{~A}_{24(9)}-\mathrm{B}_{5}-\mathrm{Cw}_{1}, \mathrm{~A}_{11}-\mathrm{Bw}_{22}-\mathrm{Cw}_{1}$ の組合わせを 持つ者が，常習飲酒歷のある痴呆に多く，長年多量飲 酒を続けているにもかかわらず痴呆にならない老人で は, $\mathrm{A}_{24(9)}-\mathrm{B}_{7}-\mathrm{CW}_{7}, \mathrm{~A}_{2}-\mathrm{B}_{5}-\mathrm{CW}_{3}, \mathrm{~A}_{2}-\mathrm{B}_{7}-\mathrm{CW}_{7}, \mathrm{~A}_{24(9)}$ $\mathrm{BW}_{35}-\mathrm{CW}_{3}$ が多かった。

\section{7. ダウン症における加齢と心身機能の変化}

都老人総合研究所心理・精神医学部

$$
\begin{array}{llr}
\text { 柄澤 } & \text { 昭秀, 本間 昭 } \\
\text { 笠原 } & \text { 洋勇, 川島 } & \text { 寛司 }
\end{array}
$$

人口の高齢化に伴い, 昔は短命とされていた精神薄 弱者の寿命も延長した。精神薄弱者の施設に㧊いても, 中高年者は段々に増加して和り, 老化対策は今や重大 な課題の一つとなっている。この問題との取り組みの 中で今回われわれは, 精神薄弱の中でもとくに早老傾
向があると言われているダウン症をとり上げ，その心 身機能の特徵と加齢変化について明らかにすることを 試みた。

対象は東京都の某施設利用者である。この施設は割 合歴史が古く, 中高年者の割合が高く, ダウン症者の 数も多い. 20 歳以上の精神薄弱者 428 名に対し, 精神科 医による健康診査, 生活指導員による日常生活評価, そして可能なケースには心理テストによる知的能力評 価が行われた。このうちダウン症者は 62 名 $(20 \sim 49$ 歳 $)$ である，ダウン症者と年齢を注ぼ同じくした非ダウン 精神薄弱者155名を対照群として, 両群の比較検討を 行った. 結果の要約は次のようである.

1) 成人ダウン症群は対照群に比べて, 長谷川式知的 機能スケールの平均得点がやや低かったが, 日常生活 能力のレベルは両者間に大きな差はなかった。また明 らかな年齢差は認められなかった。

2）外見上の老化指標はダウン症群の方が対照群よ り高く, 年齢による差が認められた. ダウン症には白 内障の合併が著しく高かったが，てんかん発作の合併 は対照群より少かった。 高血圧や脳卒中, 糖尿病, 心 筋梗塞, 関節痛, 神経痛等はほとんど見られなかった。

3) 成人精神薄弱者とアルッハイマー型老年痴呆の 知能障害のパタンには差異が認められた。 35歳を越兄 たダウン症の脳にはアルッハイマー病のそれと類似し た病理的変化が現われると言われているが, 今回対象 となった成人ダウン症の大多数は, アルッハイマー病 を強く疑わせる症状変化を示さなかった。

\section{8. 老年期痴呆患者の包括調查研究一第 4 報一調査 項目間の関連性と調査対象の経過}

浴風会病院内科

同 精神科

関東学院女子短大家政科
篠原 恒樹 竹中 星郎 手嶋登志子
前報までに老年期痴呆の入院患者 (D 群) 49名の過 去の食生活を中心とした生活習慣について，対照であ る痴呆のない入院患者 ( C 群) 50 名, 痴呆のない養護老 人ホーム在住老年者 $(\mathrm{H}$ 群 $) 50$ 名のそれと比較し, D 群 に特異と思われる項目を見出して報告してきた。

今回はそれら項目間の関連性を分析するとともに, 対象三群の経過, 主に死亡, 死因について調查を行っ たので報告する。

食生活を除いた過去の経歴や習慣の項目と食生活に 関する項目の間では, D 群に沶いて“食事量と肥満”, C 群に扣いて, “食欲と肥満”, “食事量と肥満”の間に 
相関を認めたのみであった。食生活に関する項目間の 分析では D 群のみならず， C 群にも $\mathrm{H}$ 群にも共通し て関連性ありと認められた項目間の組合せとしては, “その他の野菜をよくとった”との回答と “緑黄色野菜 をよくとった”との回答, “塩味を好んだ”と“塩・しょ らゆをよくとった”，“甘味を好んだ”と“甘い菓子類 をよく食べた”，“辛味を好んだ”と“香辛料をよくとっ た”，“食事量は多かった”と“食欲は旺盛であった”, の 5 通りの組合せであり，いずれも首肯できる常識的 な組合せであったが，D群に扔いてのみ関連性ありと 認められた項目間の組合せは，“甘いのみものをよく とった”と“その他の野菜をよくとった”、“甘味を好 んだ”と“塩味を好んだ”。“冷たいものを好んだ”と “塩・しょらゆをよくとった”“食欲は旺盛であった” と“塩味を好んだ”, 又は“冷たいものを好んだ”など の数通りの組合せであり, いづれも常識的には考光に くい組合せであった。

4 年間に亘る追跡調查によると, D 群は 30 名が死亡 し, $\mathrm{C}$ 群では16名の死亡であって, $\mathrm{D}$ 群の死亡率は $\mathrm{C}$ 群の約二倍であった。剖検の許された $\mathrm{D}$ 群 25 例, C 群 15例について, 死因を心脈管系疾患, 感染症, 癌, そ の他疾患の四つに分けて分析すると, D 群では癌死が 少なく, その他疾患が多いのが特徵的であった。

\section{9. 施設老人における精神障害と心身機能}

都老人研

本間 昭, 柄澤 昭秀, 笠原 洋勇

菊池病院

川島 寛司

千本病院

加藤 政利

聖マリアンナ医大神経精神科

平田 進英, 池田 一彦, 石井 徹郎

特別養護老人ホーム在住者を対象とした比較的大規 模な精神医学的調查は長谷川らによるアンケート方式 を用いた全国調査を別にすると比較的少ない，専門的 調查によって特別養護老人ホーム利用者の精神医学的 実態を明らかにすることは老人ホームに打ける老人処 遇を実践する上で重要な基礎的資料となる。

東京都内の特別養護老人ホーム 2 施設に在住する 605 人に対して精神科医による個別面接調査を行ない, 対象者の心身機能と精神的健康の実態を明らかにし た。調査は一定の調査票を用い, 既往歴, 血圧, 身体 的障害, 日常生活機能, 現在の身体疾患, 失禁の有無 と程度, 会話の理解, 意志表示, 情緒表出, ボケの有 無打よび柄澤の基準によるボケの程度, 主要精神症状,
性格上の問題, 問題行動の有無とその種類, 精神医学 的診断, 精神科的治療の有無, 身体的招上び精神科的 医療と介護の必要度等について行なった。

入院あるいは死亡によって面接が不能であった $40 人$ を除く 565 人に対して調査が可能であった。年齢は 63 103歳であり, 平均 83.0 歳であった. ボヶは $74.2 \%$ に認められ, 診断別ではアルッハイマー型痴呆 $25.8 \%$, 脳血管性痴呆 $36.5 \%$ ，その他あるいは原因不明の疾呆 $11.2 \%$ ，その他のボヶ $26.5 \%$ であった。精神薄弱者は $2.3 \%$ (13人)であり， うち 7 人は痴呆と合併していた。 明らかにアルッハイマー型痴呆と合併していると考克 られた老人は 3 人であり, 脳血管性痴呆との合併は 1 人であった。らつ病, 分裂病, 神経症揖よび妄想状態 などを示す老人は $4.5 \%$ に認められた。約 $7 \%$ の老人が 向精神薬を服用していた。

\section{0. 痴呆老人生活指導ホームの現状と問題点に関し てー入所期間中の評価とアンケート調査の検討}

浜松医大精神科 星野 良一, 藍沢 鎮雄 村田 桂子, 大原健士郎

社会福祉法人楽寿会 有馬 良一

静岡県では, 在宅の痴呆老人を対象に 3 週間専用施 設に入所して行動観察, 精神医学的評価などを行ない, 介護する家族に助言・指導をし, 痴呆老人の在宅ヶア を援助する, 痴呆老人生活指導ホームの事業を全国に 先がけて昭和 60 年より実施し, 現在 4 施設が運営中で ある、今回はその中の一施設である静岡市の社会福祉 法人楽寿会が運営する生活指導ホームに昭和 60 年度に 入所した 60 名を対象に，入所期間中の評価とアンヶー 卜調査の結果から，本事業の問題点と現状について検 討した。

対象の性別は男性17名，女性43名で女性が多く, 85 歳以上の年齢層では全例が女性であった。これと関連 して，主な介護者は男性例では配偶者である場合が多 く，女性例では嫁である場合が多かった。

痴呆の程度では, 男女とも中等度の例が最も多く, 次に高度の例が多かったが，軽度の例は注とんどが女 性であった。また，知的機能の評価に用いた WAIS 言 語性下位検査では, 痴呆の程度によらず，類似問題の 低得点が示され, 概念操作や抽象的思考能力の低下が 共通した現象として示された。

退所後のアンケート調査では, 痴呆の理解ができた, 指導書・介護法が参考になったという回答が $80 \%$ 程度 示され，家族への助言・指導は一応の効果があったと 
考兄られた。 また, 退所直後では $30 \%$ に問題行動の減 少が報告されたが, 退所 1 カ月後では問題行動の減少 という評価は $20 \%$ に減少して抢り，持続的な効果をも たらすことの困難さが示唆された. 退所後 6 力月時点 では, 2/3以上が在宅でのヶアを続けて招り, 本事業は 部分的ながらも効果をあげていると考兄られたが，介 護体制や家族内の問題から，老人病院への入院や施設

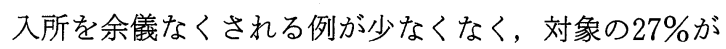
退所後 1 年以内に死亡していることから，身体面の管 理, 精神科的治療, 家族の負担軽減を含めた総合的シ ステムの必要性が示唆された。

\section{1. 保健所における老人精神衛生相談について} 九大精神科 末次 基洋, 一宮 厚

老人保健事業の一環として保健所に扮いて老人精神 衛生相談が行なわれるようになった。福岡市では昭和 59年 9 月より中央保健所にて相談を受けつけている が，開設より 1 年間の相談内容を検討し，その概要を 報告する。

1 年間の相談件数は 67 件で，男性 28 人，女性 39 人， 75 歳未満 23 人， 75 歳以上 44 人であった。保健所保健婦 および嘱託医が相談, 診察に当った。相談を申し込ん だ人が誰であるかによって，また，本人と同伴して来 たかによって相談内容にいくつかの特徵がみられた。

まず，本人自身が相談を申し込んで来た 4 件は，い ずれも痴呆とは考兄られず，生理的範囲の物忘れと判 断されたが，4人とも几張面，やや強迫的でしかも活 動的な人たちであった。

本人を同伴せず，家族のみが相談に来たのは 15 件で あり，そのらち10件は本人が痴呆かどらかの相談で あった。生活状態などの情報から痴呆の可能性がある と考えられたのは 1 人だけで，アルコール依存，らつ 病の疑各 1 人, 他の 7 人は性格偏倚と推測される人た ちであった。

本人を同伴して家族が相談を希望したのは48件で あった。そのうち 42 人は痴呆があると判断された。相 談に持ち込んだのは娘が21件でもっとも多く, 妻10件, 嫁 5 件，息子 5 件などであった。妻や娘が相談に持ち 込んだ事例では徘徊や失禁などの相談者が負担になる 問題行動よりも, 相談者を含む家族が痴呆をこれ以上 進行させないためにと過敏になり，叱咜激励している ことに対する老人の反発が問題になっている例が多 かった.

嫁が相談に持ち込んだ事例は 5 件のみであったが,
そのなかで，嫁が入院・入所を希望しているが他の家 族成員が必ずしもそれに同意していないことがあっ

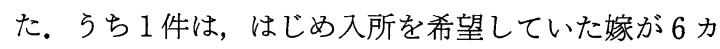
月間の継続相談により在宅介護を続けた例があった。

\section{2. 老年期の外科手術後の精神障害について 兵庫医大精神科神経科}

中川 明彦, 古橋 淳夫, 山本 博一

橋山 恵美, 永野修, 高内茂

三好 功峰

目的：最近，老年期に执いても手術適応が拡大して きているが，その反面，術後に精神的問題をきたす例 は少なくない，このため今回我々は，老年期の術後の 精神障害の特徵を調查する目的で本研究を行った。

方法 : 最近 5 年間の 65 歳以上の外科患者のうち術後 の精神障害を認め当科に往診依頼のあった 41 例（男 19 例, 女22例, 平均年齢71歳) を対象とした。対象とし た患者の精神障害を分類し, その特徵, 発症要因, 予 後を調べた。

結果 : 術後の精神障害の内訳は，せん妄26例，抑う つ12例, 痤れん 2 例, 手術を契機として痴呆の明らか となったもの 1 例であった. 原因となった手術は, 腫 瘍の手術 16 例, 心血管系 9 例, その他脳外科, 整形外 科, 消化器系各 4 例であった。 また白内障手術は 2 例 であり，いずれもせん妄であった。せせ妄に関して述 べると, 術前に貧血, 低栄養を過半数に認めた。術前・ 術後の検查異常の推移は, 電解質異常, 肝機能障害, 動脈血ガス異常, 腎機能障害はいずれも術後に検査異 常が増加した。さらに術後合併症として発熱・感染を 約半数に認めた。 また術後 ICU 入室中に精神症状のみ られた例は 6 例であり, 全例せん妄で感覚遮断の要素 が強かった。せん妄の経過は, 観察期間中に軽快した 例は16例 (61\%), 死亡した例は 8 例 (31\%) であった。 死亡例は，せん妄の持続期間が長く，また術中出血量 は平均 $1,553 \mathrm{~g}$ で, 軽快例の約 2 倍であった。抑うつに 関しては, 手術によって身体的機能を老年期に喪失す ることが精神的誘因として重要であると考えられた。 経過は，軽快が 7 例，死亡が 1 例であったが，死亡例 は睡眠薬による自殺を図ったものであった。

結語：老年期の術後せん妄の予後は, 前回報告した 老年期の一般のせん妄と比較すると不良であった。 た非老年期の術後せん妄の予後と比べても重篤であ り，その点で予後不良の因子をもつ老年期の術後せん 妄に充分から適切な治療が必要であると考兄られた。 


\section{3. アルツハイマー型痴呆の CT による追跡研究}

聖マリアンナ医大神経精神科

平田 進英, 今井 幸充, 石井 徹郎

池田一彦，坂本誠，長谷川和夫

都老人総合研究所 本間 昭

アルッハイマー型痴呆（SDAT）患者の CT 上の脳 萎縮は，その診断に有用であることは多くの研究で認 められている.しかし SDAT 患者の脳の CT 上の形態 变化についての追跡研究は数少ない.そこで演者らは, 本疾患の CT 上の変化について追跡研究を行い検討し たので報告する。

対象は, SDAT と診断された 25 名（男性 9 名，女性 16 名), 平均年齢 68.5 歳で, 追跡期間は平均 15.2 力月で あった。 また追跡前，後に長谷川式簡易痴呆スケール （HDS）を施行し，痴呆の程度は Clinical Dementia Rating（CDR）を用いて評価した。

CT 上の変化については，演者らの方法による脳䯣 液腔面積比 $(\mathrm{CSF} \%)$ ， 左右の側頭葉，前頭葉，頭 頂葉, 後頭葉, 尾状核ならびに視床の各部位の CT 值 の変化(ピーク CT 值)を追跡の前後にコンピューター を用いて計測し検討した。25名中, 痴呆の程度が悪化 した症例は16例であった，追跡前後の HDS 得点の平 均值の比較で有意の低下 $(\mathrm{p}<.05)$ が 全般性萎縮の指標である CSF\%は, 前後の平均值の比 較で, 側脳室の前角と後角を通るスライス(A-P Slice) で有意の増大を認めた。

脳の各部位に拈けるピーク CT 值は, radiological density の指標とされて抢り, 追跡期間中に右頭頂葉 と右尾状核で有意の低下 $(\mathrm{p}<.05)$ がみられた。

これらの結果と各症例の臨床症状との関連について 若干の考察を加光発表する。

354. 老人の神経生理学的検討（第 3 報）一高齢老人 及び老年痴呆の SER と脳波, CT との関係について一 大阪府立公衆衛生研究所・精神衛生部

$\begin{array}{lr}\text { 藤本 修, 太田 } & \text { 義隆 } \\ \text { 古我 } & \text { 貴史, 藤井 久和 }\end{array}$

阪大精神医学

南野 壽重, 林 英昭, 西村 健

目的：60歳以上の正常老人及び痴呆老人を対象に, 機械的刺激に上る体性感覚誘発電位 (SER) と随伴陰 性電位 $(\mathrm{CNV})$ を記録し，SER や CNV が大脳機能を 客観的に示す指標として，有効なことを報告してきた．
今回，80歳以上の高齢正常老人及びアルッハイマー型 老年痴呆者から SER を記録し, 知能テスト, 脳波及び CT による脳萎縮度と SER の頂点潜時との関係を検 討するとともに, SER の臨床有用性につき検討したの で報告する。

方法：対象は，80歳以上の高齢老人 10 名（平均 86.4 歳) 及びアルッハイマー型老年痴呆 (SDAT) 10名で ある. 60 歳以上の正常老人 29 名（平均年龄68.8歳）を 対象群とした. SER 記録は, 手掌部に機械的刺激を与 杂た時，脳波に生じる反応を50回平均加算して記録し た。また，SERの $\mathrm{N}_{2}, \mathrm{~N}_{3}$ 頂点潜時と長谷川式簡易知 的機能診査スケール(HDRS), 脳波の基礎波の周波数 及び CT スキャンによる脳萎縮度との関係につき検討 した。CTによる脳萎縮度は, 前頭葉髄液腔や正中裂の 開大, シルビウス裂の開大, 側脳室の拡大及び最上位 スライスでの脳溝の開大の程度につき点数化して検討 した.

結果： 80 歳以上の高齢老人 10 名の SER は, 正常老 人群に比較して, $\mathrm{P}_{3}, \mathrm{~N}_{3}$ 頂点潜時がわずかに延長する のみで, 有意の差異は認められなかった。一方, SDAT では，10名中 5 名に SER の全頂点潜時の延長が認め られた。また，10名中 4 名には，一部の頂点潜時の延 長がみられ，正常 SER は，1名にすぎなかった。 また， HDRS，脳波，脳萎縮度 $(\mathrm{CT})$ とも，SDAT の方が高 齢老人より異常の発現率が高かった。高齢老人及び SDAT を対象に, HDRS の得点, 脳波の基礎波の周波 数及び脳萎縮度 $(\mathrm{CT})$ と SER の $\mathrm{N}_{2}, \mathrm{~N}_{3}$ 頂点潜時との 関係を検討すると， $\mathrm{N}_{3}$ 頂点潜時の方が $\mathrm{N}_{2}$ 頂点潜時よ り，それぞれ高い相関関係が認められた。

\section{5. 健康老人における記銘力と CT 画像}

都老人総合研究所精神医学

笠原 洋勇，小林 充，矢富 直美 都老人医療センター核医学放射線部

山田 英夫，千葉 一夫，丹野 宗彦

痴呆性疾患の臨床に招いて画像診断は今や欠かすこ とができない，痴呆を対象とした画像診断の研究もと れとともにますます盛んになりつつある。しかしなが らこれまでの研究の問題点は健康老人の CT 画像を十 分に把握しないまま痴呆性疾患の画像に関する論議が されてきたことである，そこで(1)健康な老人脳の画像 はどのようなものか. (2)加齢による脳の生理的変化は ぞの範囲をいうか. (3)正常な老人と痴呆性疾患の脳画 像の境界はどこにあるか. (4) CT 画像の追跡研究によ 
り痴呆の早期発見は可能か. (5)これらをふま光て痴呆 診断に括ける $\mathrm{CT}$ 画像の判定基準を作成する。などを 目標として, 在宅ボランティア老人141例について頭部 $\mathrm{CT}$, 脳波, ベントン視覚記銘テスト, 血圧測定のほか 問診を施行した。今回は頭部外傷や脳血管障害などの 既往のない133名の健康老人について, CT の画像所見 とベントン視覚記銘テストとの関連について分析し た。な和対象の内訳は，男性 61 人，女性 72 人であり， 60 69歳29例, $70 \sim 74$ 歳 48 例, 75 79歳35例, $80 \sim 89$ 歳21例であり, 平均73.8歳であった。

CT の視覚的判定法により脳疾患の既往のない健康 老人にもかかわらず, 小梗塞 $15.0 \%$, 皮質の萎縮 $23.3 \%$, 脳室拡大 $14.3 \%$, PVL $6.0 \%$ 認めた。 また ベントン視覚記銘テストの正確数 5 点以上 $72.2 \%, 4$ 〜 3 点 $23.3 \%, 2 \sim 1$ 点 $4.5 \%$ であり平均 $5.7 \pm 1.8$ で あった. ベントンテストの正確数 (BC) と誤数 (BE) が相関を示したのは, CT の小梗塞と PVLであり, 萎 縮, 脳室拡大とは無関係であった。 またベントンテス トのカード別にみると $\mathrm{C}_{6}, \mathrm{C}_{8}$ と難度の高いカードで小 梗塞 $(+)$, PVL $(+)$ が低得点を示した。一方ベント ンテストの所見では, 省略 (OMISION), サイズの誤 り (SIZE), 左側の誤り (LEFT), 右の誤りが小梗塞 (+), PVL (+) が相関を示したにもかかわらず，萎 縮 $(+)$, 脳室拡大 $(+)$ とは関連を認めなかった。 小 梗塞やPVL が萎縮や脳室拡大より病的所見とみなし えることが示された。

\section{6. 老人の睡眠ポリグラフィ研究（第 2 報）一各年 齢群間の比較一}

都老人医療センター精神科 平沢 秀人

目的：演者は，昨年の本学会に扮いて老年者の睡眠 特徵を検討するために健康若年者を対照に睡眠ポリグ ラフィ検査を行ない報告した. その結果は, 老年者群 では若年者群に比べ stage 1,2 の軽睡眠期が多く, stage 3，4 の深睡眠期や REM 睡眠が少ないという結 果であった。乙かし老年者では, 若年者と異なり年齢 や知的機能によって睡眠パタンのバラッキが大きくな ることが考学られる。そこで今回は，老年者の睡眠特 徵のらち年齢差と知的機能について, 特に REM 睡眠 を中心に検討を行ない報告した。

対象：対象は 60 歳以上の健康老人 36 例で， 60 歳代 9 例， 70 歳代 9 例， 80 歳代 10 例，90歳代 8 例である.

万法: 万法は, 前回と同様に終夜睡眠ポリグラフィ を連続 3 夜行ない, そのらち 2 夜目と 3 夜目を記録夜
とし，国際判定基準に基づいて睡眠段階の判定を行 なった。

結果 : 各睡眠段階の出現率 (\%stage)のうち\%stage W, \%stage 1, \%stage 2, \%stage 3+4 では各年代間に 差はみられなかった。しかし,\%stage REM では年代 が増すに従い減少する傾向がみられ，特に90歳代では 他の年代に比べ有意な減少を認めた。一方, 対象老人 の知的機能をみるために心理検查 WAIS を施行し, こ のWAIS の粗点と\%stage REM を比較した. 全対象 例では有意な関連はみられなかったが，60，70歳代に おいて高い正の相関がみられた。次に REM density 調べてみたところ60歳代から70歳代にかけては有意な 減少がみられたが，80歳代から90歳代にかけてはむし ろ有意に増加した。 そこでこの REM densityと WAIS の粗点との関連を調べたところ60，70歳代では REM density と WAIS の粗点とは軽度の正の相関が みられ，80，90歳代では負の相関を認めた。

結語：REM 睡眠の量的変化は加齢に伴う脳機能の 低下と関連した現象と考号られたが，REM 睡眠の質 的変化は REM 睡眠の量的変化とは違った脳機能の変 化を反映していると思われた。

\section{7. 肺炎におけるコホート分析の 3 力国比較}

東大成人保健学 根岸 龍雄, 内藤 雅子

1. はじめに：第二次大戦後, 我が国に括ける肺炎に よる死亡率は減少傾向を示し始めたが, 近年では乳幼 児や老年の死亡率は小さくなく, 停滞気味である。本 報告は日, 米, 英の 3 力国を対象として, この 3 力国 の肺炎死亡率のコホート分析を行い, 比較検討するこ とによって, 各国の特徴を明らかにし, 今後の健康管 理に資することを目的とする。

2. 資料と方法：我が国については「人口動態統計」, 米国（白人，非白人）については「VITAL STATISTICS OF THE UNITED STATES」, 英国について は「THE REGISTRAR GENERAL'S STATISTICAL REVIEW OF ENGLAND \& WALES」である. 検討した期間は日本と米国は，1950～1980年，英国は 1951 1981年の 5 年次ごとの計 7 年次である.

3. 結果と考察：日本, 米国, 英国の男女各々につい てコホート現象が認められた。分析の結果認められた 事実は以下の通りであった。 (1)日本, 米国, 英国の男 女の肺炎死亡率の性差はほとんど認められなかった。 (2)日本，米国，英国の各国に共通して， 0 4 歳から 10〜14歳までの年齢の死亡率の減少率は約 100 分の 1 
ないし 5 で，大きな変化がみられた。 (3)日本の肺炎に よる死亡率の推移は, 米国捛よび英国の推移を追随し ているものの如くであった. (4)米国, 英国の 2 力国で は, 日本よりも若年層からゴムペルッ則に従う年齢階 級別死亡率の分布が認められた。 (5)日本と英国の男女 では死亡率の年次推移が，ある年齢を中心に反時計方 向に回転していることが示された。(6)日本と英国では コホート現象は観察期間内に 2 回認められたが，米国 では 1 回のみであった。

\section{8. 脳血管疾患死亡におけるコホート分析の 4 カ国 比較}

東大成人保健学 内藤 雅子, 根岸 龍雄

1. はじめに：本報告は, 日本, 米国 (白人, 非白人), 英国, スウェーデンの 4 力国に括ける脳血管疾患死亡 のコホート分析ならびにその比較検討を行うことによ り,これらの国の脳血管疾患死亡の動向を明らかにし， 今後の健康管理に資することを目的とするものであ る.

2. 資料と方法：「人口動態統計」(日本)，「VITAL STATISTICS OF THE UNITED STATES」(米 国), 「THE REGISTRAR GENERAL'S STATISTICAL REVIEW OF ENGLAND \& WALES」(英国) 抢よび「DODSORSAKER」（スウェーデン）を資料と して，1950１981年（日本は1950 1980，米国は 1950～1975，1979, 英国は1951～1976，1981，スウェー デンは1952 1977，1981）を資料として，5年次ごと 計 7 年次について, 性・年齢 5 歳階級別にコホート分 析を行った。

3. 結果と考察：(1) 米国白人, 英国扣よびスウェー デンの性・年次・年齢階級別死亡率曲線は, 10 歳以上 についてみると、ゴムペルッ則に従う傾向が認められ た。日本と米国の非白人に和いては中年齢層の死亡率 が低下し，徐々にゴムペルッ則に従う傾向を示し始め ていることが認められた。（2）4 カ国のコホート分析 を行ったところ, 以下の結果が得られた。 (1)日本, 米 国白人, 英国の男女では，30４0歳前後を境として, 高年齢側之若年齢側に和いて，異なった二相的な構造 的変化が認められた。(2)スウェーデンの男が不明確で あるのを除いた他は，80歳以上に拀いて死亡率が一度 増加した後に減少したことが認められた. (3)この 4 力 国の死亡率の変化の割合は男よりも女の方が大きいこ とが示された。 (4)日本に抢ける脳血管疾患の死亡構造 は, その変化に招いて他の 3 力国と若干の類似した特
徵をもって㧺り，ほぼ欧米型に近づきつつあることが 示された。

\section{9. 高齢者死亡例の臨床的病理解剖学的死因の観察 第 VIII 報 殊に悪性新生物について}

名古屋市厚生院内科

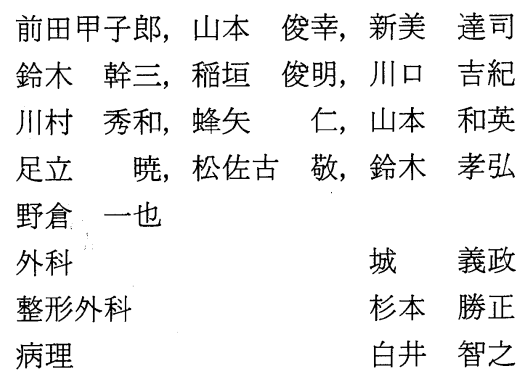

私達は厚生院に打ける連続剖検による高齢者の死因 の観察を行い, 数回に亘り本学会で報告して来た. 年 次の経過と共に対象老人の高齢化が更に進み, 医学の 発達と共に幾つかの留意すべき点がみられたので, 悪 性新生物の観察を中心に報告する.

対象は昭和 40 年 4 月から同 60 年 9 月末すでに当院で 死亡し, 剖検し得た 1,339 症例 (男645, 女694例) であ る. 年代は69歳以下 237,70 歳代 516,80 歳以上 586 例で, 前回の報告時点昭和51年 3 月末までを前期，その後を 後期として比較検討した。

成績：1）臨床死因では肺結核（前期 $2.4 \% \rightarrow$ 後期 $0.97 \%$, 脳出血, 脳硬塞, 消化器疾患, 腎・尿路疾患 は減少を, 心疾患 $(25.5 \% \rightarrow 26 \%)$, 悪性新生物 $(16.9 \%$ $\rightarrow 16.0 \%$ ）は著変なく, 逆に動脈硬化に基因する大動 脈破裂などその他疾患 $(6.1 \% \rightarrow 12 \%)$ が増加し, 死因 の多様化が目立った。 2) 病理死因では, 脳硬塞が後期 で 1 例と激減し, 脳出血, 肺結核, 消化器疾患, 心疾 患, 悪性新生物も減少し, 逆にその他疾患, 肺炎, 大 動脈瘤破裂などが増加した。年代別にはその差は殆ん ぞみられなかったが，超高齢者に悪性新生物の低いの が目立った。 3）悪性新生物については, 死因と関係な く病理所見で悪性新生物陽性例をみると前期では 181 名 $(23.1 \%)$, 内腫瘍死 111 件 $(17.9 \%)$, 後期では 181 名 $(29.3 \%)$, 内腫瘍死78件 (12.5\%) と, 悪性新生物 の発生は増加傾向にあるが，他疾患併発による死亡が 多く, 腫瘍死は減少傾向にある. この傾向は超高齢者 で明らかで, 後期の 90 歳以上でみると腫瘍死は $3.6 \%$ と 低いが, 病理所見腫瘍陽性例は $24.3 \%$ と高率であった。 更に, 藏器別には前期で胃癌 $29.8 \%$, 肺癌 $9.3 \%$, 重複 癌 $5.0 \%$ であったが, 後期ではそれぞれ $21.9 \%, 20.3 \%$, 
$5.4 \%$ と胃癌の減少, 肺癌の増加が著明であった。

以上, 高齢者では常に癌の存在に留意しなければな らないことを再確認した。

\section{0. 老人の健康診査受診行動と関連要因}

国立公衆衛生院疫学部

䈌野 脩一, 藤田 利治, 䇾輪 真澄 久保奈佳子, 竹内 和子

目的と方法：老人の半数は有病者であり, 老人健診 の目的及び有効性に関しては論議のある所であるが, 健診受診行動の実態とこれに関連する要因を明らかに することを目的として，大都市一部，一地方都市，一 農村地域の 3 地区の 60 ～89歳の老人の無作為標本 3,440 名についての面接調查成績を解析した。

結果：現に医師受療中の者は健診受診の必要が低い と思われるが，外来受診回数の多い者がむしろ健診受 診率が高かった. 1 年以内の入院歴は影響がなかった。 受診中の者では 5 歳区分年齢階級でみて84歳までが 70\%を越えていた，受療していない者でも60～74歳間 は60\%を越光，75～84歳までは $50 \%$ 越光た。受療中 の者は当該疾患以外の検査を受ける機会があるので, 非受療者中の健診未受診者が問題である。そこで非受 療者に打いて健診受診率を $50 \%$ 以下に低下させた条件 を求めると, 年齢85歳以上, 現住所居住歴 10 年未満の 男, 学歴小卒以下, 健康の自己評価で良くないとする 者, 日常生活に支障を来たすような疾病のある者, と くに脳卒中, 骨・筋肉疾患, 骨折等受診のための移動 に困難があると思われる者, 視聴力低下がありコミュ ニケーションの困難な者, 物がよく嚙めない者, 家事 や仕事をしていない者, 近隣とのつきあいが添とんど ない者, クラブ活動等では名義だけの参加者, 女で酒 または煙草を嗜む者であった。現在医師を受療してい ない者について，健診受診率を $70 \%$ 以上に高める条件 としてはクラブ活動等の積極的活動があった.

これらの諸条件の中我々が有効に介入しらる条件は 限られようが，さらに整理を進めて地域毎の特徵も浮 き立たせることがでさよう。

結語：我が国の大都市, 地方都市, 農村地域の在住 高齢者の健康診査受診行動の実態を明らかにし，受診 を妨げる要因を確認, ハイリスク集団を同定した。こ の成績は老人健診の成績向上及び評価に役立たせるこ とができょう。

\section{1. 農村地域における高齢者の健診受診行動につい}

\section{ての検討}

\section{日本医大老研}

高橋 修和, 荒井 敦子, 大橋 知子 1981年より山梨県早川町住民の健診を実施してき た.この町は山岳地帯で町を流れる河川の流域に部落 が点在している。人口は 1985 年 7 月現在 2,001 人でその らち65歳以上の年齢層は 682 人で人口に対し $34.1 \%$ 占めている. 1981年から 5 年間の 65 歳以上年齢層の健 診受診率は 1981 年 $51.4 \%$ ，その後 $42.3 \%, 56.8 \%$, 47.0\%，46.5\%であった。

今回我々は 65 歳以上の年齢層の健診受診行動につい て検討した. 1985年現在, 過去 5 年間調査地域に居住 している65歳以上の者を対象者とし，この間に健診を 3 回以上受診した者を受診者として受診率を算出し た.

まず地区別に受診率をみると本建地区 $43.2 \%$ ，五箇 地区 $59.9 \%$ ，硯島地区 $56.6 \%$ ，都川地区 $48.1 \%$ ，三里 地区 $45.4 \%$ ，西山地区 $56.3 \%$ で地区によりわずかなが ら差がみられた。これをさらに性別でみると都川地区 を除いたすべての地区で男が女より高率を示してい た。性別年齢別受診率では男は65～69歳52.9\%, 70 74 歳 $59.2 \% ， 75 \sim 79$ 歳 $60.4 \% ， 80$ 歳以上 $38.7 \%$ ，女はそ れぞれ $55.2 \% ， 52.2 \% ， 48.8 \% ， 33.3 \%$ と加齢に伴い 低率となっている，次に世帯構成別に受診率を検討し た。家族と同居世帯では $46.5 \%$ ，一人暮し世帯では $50.0 \%$ ，夫婦の久の世帯では $58.8 \%$ の受診率となって いた。これを地区別にみると家族と同居世帯では都川 地区が $34.0 \%$ と低率でそれ以外の地区は $41.1 \sim 56.8 \%$ を示し，一人暮しの世帯では三里，本建地区がそれぞ 孔30.6\%，38.5\%と低率でそれ以外の地区は 44.4 61.8\%, 夫婦のみの世帯では本建地区 $43.3 \%$, それ以外の地区は53.2〜 73.9\%であった。性別にみる と男では一人暮し世帯が $33.4 \%$ ，女では同居世帯が $42.7 \%$ で低率となっている。逆に高率を示しているの は男女とも夫婦のみの世帯であった。

さらに過去の健診結果, 既往歴, 社会的要因々の関 連についても検討を加える。

362.ラットにおける自家蛍光色素沈着とビタミン $\mathbf{E}$, 脂肪摂取量との関連

愛知県がんセンター 佐藤 秩子
愛知医大加齢医科研

田内 久, 甲谷 憲治, 水野 俊昭 消耗性色素（リポフスチン）の加齢に伴う増加につ 
いての報告は多いが，必ずしも老化の形態学的指標と して本質的なものではない点を私どもは種々の成績を 示して強調してきた。今回は帝京大生化学教室との協 同研究による成績の一端を報告する。

$\mathrm{SD}$ ラットを生後 4 週よりビタミン $\mathrm{E}$ 欠乏食（3\% コーン油)， $\mathrm{E}$ 添加食 (3\%, 及び18\%コーン油)で飼 育し, 4 力月, 12 力月後に屠殺剖検し各臟器組織内の リポフスチン（自家蛍光色素としてとらえた）を形態 学的定量分析して比較した. ビタミン $\mathrm{E}$ 欠乏群では 12 力月飼育群のみに筋細胞（前脛骨筋，咬筋，舌筋）内 に散発的に筋細胞の崩壊, 自家営光色素の多量の発現 を局所的に認めたが, 赤脾䯣細胞, 腎尿細管主部上皮 等では細胞の変性はなく, 極く僅かな色素の増加（有 意ではない）を認めたのみで，一方 $\mathrm{E}$ 添加 $18 \%$ コーン 油群では，4 カ月，12力月ともに他の 2 群に比して有 意に各藏器組織内に多量にこの色素が認められた（筋 細胞を除く). 気管支上皮，小脳プルキンエ細胞におい てはその差は有意ではなかった。自家蛍光色素の沈着 とビタミン $\mathrm{E}$ と関連を一面では認めることは出来 るものの, この色素の沈着は絶えず変動する細胞の脂 質代謝の一面の表現に過ぎず，この色素の沈着が直ち に老化の指標になるとは考学られず既に私どもが在八 ワイ日本人例の肝細胞に, 在日日本人や在米白人に抒 けるとは異なって, 若年で既に多量に認められたのと 同様に，栄養条件特に脂肪の摂取量とも密接に関連す る極めて流動的な細胞機能様相の一表現と考古たい。 臓器組織によってその沈着様相, 脂肪摄取量との関連 性も異なり，必ずしも fixed post mitotics の細胞に多 いとも限らないのも説明出来るかと思われる.

\section{3．痛風における血清過酸化脂質に関する研究} 東大物療内科西田琇太郎, 宮本 昭正 帝京大第二内科 藤森 新, 赤岡 家雄 過酸化脂質 (LP) が種々の組織を障害することは明 らかにされている。近年 LP は血小板凝集や動脈硬化 との関連が注目されている。一方, 痛風では動脈硬化 性疾患による死亡が増加している。今回, 原発性痛風 で血清 LP を測定し，合併症との関連等について検討 した.

方法: 東大物療内科外来一通院中の原発性痛風 45 例 (平均年齢56.4 12.7 歳, 全例男性), control として健 常男性30例（平均年齢55.1 10 10.0歳）より朝食前に採 血した. LP濃度は八木らの方法によるWako-kit （Lipoperoxide-Test）を用いて定量した.
結果: 血清 LP の平均値は control 群 $3.52 \pm 0.85$ $\mathrm{nmol} / \mathrm{m} l$ に比し痛風群では $7.53 \pm 3.05 \mathrm{nmol} / \mathrm{m} l$ と $1 \%$ の危険率で有意の高値を示した。痛風症では $20 \%$ に心電図で Minnesota Code による虚血性変化を示し たが, これらの群の血清 LP の平均值は $8.9 \pm 4.1$ $\mathrm{nmol} / \mathrm{m} l$ と虚血性変化のない群の $6.8 \pm 2.1 \mathrm{nmol} / \mathrm{m} l$ に比して有意の高值を示した。痛風群で血清 LP 值と 心電図の虚血性変化の関連は $5.0 \mathrm{nmol} / \mathrm{m} l$ 以下では $10 \%, 5.0 \sim 10.0 \mathrm{nmol} / \mathrm{m} l$ では $17.8 \%, 10.0 \mathrm{nmol} / \mathrm{m} l$ 以上では $42.8 \%$ と血清 LP 值の上昇と共に虚血性変化 の頻度も増加した。 しかし血清 LP 值は血清尿酸値, 体 重, 年齢, 腎障害の合併の有無等とは関連を示さなかっ た. 血清 LP は冠動脈硬化の risk factor である可能性 が示唆された。

\section{4. 遺伝性ビタミン $\mathrm{C}$ 合成不能ラット（OD ラット） における老化の指標 \\ 名大老年科河野 和彦, 早川 道彦 浅井 幹一, 葛谷 文男 \\ 同 眼科原田 敬志}

目的：ODラットは，ヒトと同様に L-gulono lactone oxidase の先天的欠損によりビタミン C 合成 が全く不能なラットである。すでに，第27回老年医学 会総会に打いて, 貧血, 血小板数減少, 胸腺低重量, 低 HDL-コレステロール血症, ADP による血小板凝集 能充進, 大動脈コラーゲン形成不全を報告した。今回 は長期生存に成功した個体にみられた病理組織等から 老人の疾患に類似すると思われた所見をまとめて報告 する。

方法：ホモ接合体の OD ラット (ODS-od/od) 雄10 匹とコントロールラット(ODS-+/+) 雄10匹に対し, アスコルビン酸 (AsA) 無投与で生後63日にて屠殺し, 病理組織の検索. また, ODS-od/od 雄 7 匹に対し, AsA $5 \mathrm{mg} / \mathrm{kg}$ 体重/日を連日投与と隔日投与の期間にて与 兄, 体重減少と壊血病症状の出現, 消退を確認しつつ 体重200g を維持させた。

結果: 生後63日の OD ラットは, 骨重量がコント ロール406 $\pm 17.0 \mathrm{mg}$ (大腿骨右側) に対し $148 \pm 33.4 \mathrm{mg}$ ときわめて高度な皮質菲薄化等の形成過小の状態を示 した。肺と肝には細菌性敗血症による膿瘍が多発し, その原因として液性免疫の低下が推測された。すなわ ち, 脾に打いてB細胞の消失が著しく，また胸腺に拉 いても技そらくはマクロファージの formy cell 化が みられ，細胞性免度の低下も考光られた。 AsA 投与に 
て延命させた場合, 最長生存日数が307日に達し, 途中 採血の為死亡した 2 匹を除く 5 匹の全眼の角膜実質に 電顕的に新生血管を認め， 2 眼に肉眼で認められる角 膜混濁を呈し，これは光顕的に角膜虹彩炎を示した。 白内障は認めなかった。また,多かれ少なかれ OD ラッ トの肺には沉小葉性肺気腫が認められ, 肺弾性線維の 構築不全というょり閉塞性肺病変からの二次的な肺胞 壁破壊と考兄られた.

考察: OD ラットの骨粗鬆症, 免疫力低下, 汎発性肺 気腫様変化及び角膜虹彩炎のビタミンC 久乏との一 義的関連は，今後の研究課題である。老年者のビタミ ンC 欠乏と考えあわせ興味深い.

\section{5. 老人肝薬物代謝能に対するマロチラートの影響} 一代表的指標薬物による検討一

昭和大薬理学

$$
\begin{aligned}
& \text { 小林 真一, 甲斐 研一, 小口 勝司 } \\
& \text { 坂本 浩二, 安原 一 }
\end{aligned}
$$

第27回本学会で我々は trimethadione (TMO), antipyrine (AP) を指標薬物とし老人の肝薬物代謝能 を検討し，酸化的薬物代謝は脱メチル化反応が低下し ていることを報告した。そこで今回, 肝での蛋白合成 作用を有し臨床で肝硬変患者に投与されているマロチ ラート（MAL）を老人患者に投与した場合の酸化的肝 薬物代謝能を検討した。

方法：対象は低アルブミン血症以外に臨床検査で著 変を認めない寝たきり老人女性患者 5 名 (平均年齢 86.6 歳，平均体重 $36.7 \mathrm{~kg}$ ) で MAL (200mg, t.i.d)を $2 \mathrm{M}$ 経口投与した。 $\mathrm{TMO}(4 \mathrm{mg} / \mathrm{kg})$ は MAL 投与 $2 \mathrm{M}$, 投与終了後 $1 \mathrm{M}$ に経口投与し, $\mathrm{TMO}$ 投与後 $4 \mathrm{Hr}$ に採 血し TMO 和よび代謝産物 dimethadione (DMO) の 濃度を測定し血中 DMO/TMO 比を検討した. AP (7 $\mathrm{mg} / \mathrm{kg}$ ) は MAL 投与 $1,2 \mathrm{M}$, 投与終了 $1 \mathrm{M}$ に経口投与 乙 $\mathrm{AP}$ 投与後 $24,48 \mathrm{Hr}$ 蓄尿し尿中 $\mathrm{AP}$ 招よびその主 要代謝産物3-hydroxymethyl-AP(3HM), 4-hydroxy$\mathrm{AP}(4 \mathrm{OH})$, nor-AP(NOR)濃度を測定した。 また free cortisol (FF) と $6 \beta$-hydroxycortisol $(6 \beta$-OHF) 濃度 は MAL 投与 $2 \mathrm{M}$ に測定し, 尿中 $6 \beta-\mathrm{OHF} / \mathrm{FF}$ 比を検 討した。これらの值はMAL 投与前値とそれぞれ比較 検討した。

結果：MAL 投与により老人患者では血中 DMO/ $\mathrm{TMO}$ 比が投与前值に比し $51 \%$ 減少した。尿中 $4 \mathrm{OH}$ は $63 \%$ 増加, NOR は37\%減少した. 尿中 $6 \beta-\mathrm{OHF} / \mathrm{FF}$ 比 は42\%増加した。これらの変化は MAL 投与終了 $1 \mathrm{M}$
後には前値に回復していた.

考察：TMO, AP および cortisol は肝薬物代謝酵素 (cyt. P-450) で酸化的代謝を受ける. $4 \mathrm{OH}, 6 \beta$-OHF は水酸化反応により, NOR, DMO は脱メチル化反応 によりそれぞれ産生される。 MALは老人において4 $\mathrm{OH}, 6 \beta-\mathrm{OHF} / \mathrm{FF}$ 比を増加させ, NOR, DMO/TMO 比を減少させた。 以上の結果, MAL は水酸化反応を促 進させ，脱メチル化反応を抑制させ，それぞれ異なる cyt. P-450 isozymeに影響を与えたことが示唆され た.

\section{6. 老年者における乳酸アシドーシスの臨床的検討} 都老人医療センター内科

磯㠃 泰介, 深山 牧子, 稲松 孝思
中野 忠澄, 井藤 英喜

対象・方法：昭和 $54 \sim 60$ 年の 7 年間に東京都老人医 療センターに打いて経験された14例の老年者の乳酸ア シドーシスに関し，基礎疾患，誘因，アシドーシスの 種類掞よび程度，予後等につき検討を加えた。

結果：1）老年者の乳酸アシドーシス14例の基礎疾 患として感染症 ( 5 例), 固型癌 ( 2 例), 糖尿病・肝 硬変・悪性リンパ腫・甲状腺機能低下症・イレウス・ 多発血栓症を認めたが，同一症例に複合疾患を認める 例が多かった，2）誘因としてショック（6例), 脱水 (4 例), DIC ( 3 例), 血糖値異常 (高血糖 1 例, 低血 糖 1 例), 腫瘍の急速な増大などがみられた。(重複を 含む).3）乳酸アシドーシスの型としては tissue hypoxia 伴 5 IIa 型が11例と多く, tissue hypoxia を伴わないIIb 型は 3 例であった。I 型はみられな かった。 4）血中乳酸值は $55.7 \pm 26.1 \mathrm{mg} / \mathrm{d} l$, 血中ピル ビン酸値は $1.78 \pm 1.52 \mathrm{mg} / \mathrm{d} l$, 乳酸/ピルビン酸比は $101.9 \pm 185.5$ (全例10以上) であった. 5) 動脈血 $\mathrm{pH}$ は7.29 \pm 0.17 , anion gapは $25.9 \pm 8.0 \mathrm{mEq} / l$ であっ た. 6) 乳酸アシドーシス 14 例のうち, 10 日以内の死亡 例が 10 例(平均 $3.8 \pm 2.9$ 日) と予後は極めて不良であっ た。しかし他の 4 例は乳酸アシドーシス改善後少なく とも 2 年間生存した. 7) 死亡例の血中乳酸值は $57.2 \pm$ $26.1 \mathrm{mg} / \mathrm{d} l$, 血中ピルビン酸值 $1.51 \pm 1.43 \mathrm{mg} / \mathrm{d} l$, 生存 例の血中乳酸值 $52.0 \pm 29.9 \mathrm{mg} / \mathrm{d} l$, 血中ピルビン酸值 $2.40 \pm 1.72 \mathrm{mg} / \mathrm{d} l$ で, 死亡・生存両群間に括ける血中 乳酸・ピルビン酸值に有意差はみられなかった。死亡 例（10例）の誘因は DIC（ 3 例)，ショック（5例）が 多いのに比し, 生存例 4 例中 3 例は DIC もショックも 認めなかった。他の 1 例は敗血症性ショックに対しド 
パミン投与により血圧を維持しつつ腹膜透析にて乳酸 アシドーシスを治療した例であった。

考察：老年者に扮ける乳酸アシドーシスの誘因とし て感染症性ショック, DIC, 脱水出血等による tissue hypoxia を誘因とする事が多く，ショック・DICを誘 因とした乳酸アシドーシスの（IIa）の予後は極めて不 良だった。

\section{7. 在宅痴呆老人介護者の問題について}

秋田県立脳血管研究センター

$$
\text { 前田 隆, 鈴木 一夫 }
$$

目的：農村地区を主体に秋田県の在宅痴呆性老人と その介護家族の実態と問題点を明らかにし，今後の医 療福祉制度のあり方について検討する。

対象及び方法：昭和60年 9 月に全国社会福祉協議会 が行なった「在宅痴呆性老人介護者実態調査」及び, 同時に秋田県が行なった「介護者・患者関係アセスメ ント」に有効回答が得られた492名を対象とし，とくに 介護者自身の悩みと痴呆老人の日常生活動作の関連を 介護者・患者アセスメントの分析を通して評価した。

結果：介護する上で問題のあると思われる「自殺や 心中を考学た」，「家出を考学た」，「家庭生活そのもの が不安」など精神的に追い詰められた経験をもつ群で は，「老人のことで愚痴をいう」，「老人が愚痴をいら」, 「でかけるときあなたに声をかけない」「注意すると怒 る」, 「乱暴する」,「別居している子供が訪ねてこない」, 「介護を代わる身内がいない」，「介護でくたびれる」， 「敬老の精神が失われつつあると思う」の項目で他の群 と差がみられ，介護者と老人や他の家族との関係がう まくいっていないことを思わせた。

一方，日常生活動作の重症なケース（食事，排泄に 介護を要する）をかかえている群では軽症群より良好 な人間関係が保たれていた。

その結果，精神的に追い詰められた経験を持つ介護 者は必ずしも日常生活動作の重症なケースをかかえて いるわけではなく，むしろ老人を含め周囲との人間関 係に問題点のあることが推測された，今後痴呆老人の 介護者に対する援助を考劣るとき，単に老人の日常生 活動作の重症度のみならず，介護者を取り巻く，人間 関係にも注意し適切な福祉施策を検討する必要がある
と考えられた。

\section{8．裖瘡の臨床的検討一第 1 報一基礎疾患，増悪因} 子にっいて

$$
\text { ブース記念病院内科 }
$$

藤原ひとみ，福井とみ子 福沢 鹿生, 長崎 太郎

同 皮膚科 村木 良一

目的及び方法：最近 2 年間に経験した褯瘡患者のう ち, 比較的長期間観察しえた18例を対象に, 基礎疾患, 部位・臨床経過，検查所見等につき検討した。

結果：年齢は 57 歳から 86 歳に打よび，70代 80 代に多 発していた。性別は，男子10例，女子 8 例であった。 基礎疾患, 誘因では, 脳血管障害が 16 例 $88 \%$ を占め, 骨折例（3 例）では，骨折部位と裖瘡部との部位的関 連性が示唆された。初発部位は，仙骨部(14例)，踵部 （3 例)，大転子部 ( 2 例)，腸骨棘部（2 例）などに多 くみられた。 また，初発時より数力所に多発した症例 では，多くが予後不良であった。

これら自験例につき，経過，予後から，軽快群（肉 芽形成が良好で，裖瘡の進展や拡大傾向のないもの） 中間群抒よび増悪難治群（肉芽形成がみられず，他部 位への拡大や深部組織への進展が顕著なもの）の 3 群 に分類した。軽快群, 中間群は各 5 例, 増悪難治群は 8 例であった．各群の検查所見のうち，血色素量では 明らかな差異は認めなかった。アルブミンは，軽快群 では各例とも $3 \mathrm{~g} / \mathrm{d} l$ 以上を示すのに対し, 増悪難治群 では各例 $3 \mathrm{~g} / \mathrm{d} l$ 以下であり, ことに $2.5 \mathrm{~g} / \mathrm{d} l$ 以下の例 が目立った。

このうち，増悪難治群に注目し，増悪因子検査所見， 予後策を検討した，増悪因子としては，感染症（裖瘡 部の二次感染, 尿路感染等) に加兄, 消化管出血, 低 アルブミン血症がみられた。低アルブミン血症は，裖 瘡治癒を遷延化させ，一方裖瘡部よりの大量の渗出液 排出が低アルブミン血症を助長するという悪循環を繰 り返すと考兄られた。検査所見としては，著明な低ア ルブミン血症の持続と増悪時に拈ける貧血の悪化が特 徵的であった。 またこれらの例では, 増悪後 2 週ない し 3 力月以内に死亡して招り, 裖瘡悪化が生命的予後 と関連していることが示唆された。 